\title{
Is a Household Debt Overhang Holding Back Consumption?
}

\begin{abstract}
The recent plunge in U.S. home prices left many households that had borrowed voraciously during the credit boom highly leveraged, with very high levels of debt relative to the value of their assets. Analysts often assert that this "debt overhang" created a need for household deleveraging that, in turn, has been depressing consumer spending and impeding the economic recovery. This paper uses household-level data to examine this hypothesis. I find that highly leveraged homeowners had larger declines in spending between 2007 and 2009 than other homeowners, despite having smaller changes in net worth, suggesting that their leverage weighed on consumption above and beyond what would have been predicted by wealth effects alone. Results from regressions that control for wealth effects and other factors support the view that excessive leverage has contributed to the weakness in consumption. I also show that U.S. households, on the whole, have made limited progress in reducing leverage over the past few years. It may take many years for some households to reduce their leverage to precrisis norms. Thus, the effects of deleveraging may persist for some time to come.
\end{abstract}

he bursting of the U.S. housing bubble inflicted enormous damage on
household finances. Besides contributing to a significant decline in the
net worth of homeowners, the plunge in home prices left many of those
who had borrowed voraciously during the credit boom highly leveraged,
meaning that they had very high levels of debt relative to the value of their
assets. Analysts often assert that this "debt overhang" created a need for
household deleveraging that, in turn, has been depressing consumer spend-
ing and impeding the economic recovery.
The past few years have indeed seen both a sizable decline in aggre-
gate household debt and weak growth in aggregate consumer spending.
However, the nature of the relationship between these two developments 
is not well understood. According to the simplest models used by economists, a household's consumption is determined by its income (actual and expected), wealth, preferences, and the return it earns on savings. In slightly more refined models, the uncertainty faced by a household plays a role, as does its ability to borrow. However, debt does not typically exert an independent influence on consumption in traditional models; rather, borrowing is presumed to vary with consumption, as the latter rises and falls in reaction to changes in its determinants.

The traditional framework points to many factors that may be contributing to the lackluster performance of consumer spending in recent years. Wealth losses, weak income growth, and limited availability of credit, as well as a more uncertain and pessimistic outlook for future income, would all be expected to have depressed spending. Within the traditional framework, the observed decline in debt over the past few years would be interpreted as the result of weak consumption growth rather than a driving force in and of itself.

This paper asks whether a need to reverse the run-up in leverage that arose from the credit boom and subsequent collapse in home prices is in fact contributing to the recent weakness in consumer spending. To test this deleveraging hypothesis, I look at whether the households with the greatest mortgage leverage several years ago have reduced their spending the most, all else equal. I use household-level data so that I can control for other factors that might have led highly leveraged households to have different patterns of consumption than their counterparts with less leverage.

High levels of debt and leverage might have had an independent influence on consumer spending for several reasons. First, some households may target a given level of leverage; the sharp rise in leverage that occurred with the slump in home prices may have induced these households to pare back their consumption in order to pay down debt. Second, financial institutions are typically less willing to lend to more highly leveraged households. As a result, the rise in leverage has impeded some households from borrowing more to finance consumption and has prevented others from raising their discretionary cash flow by refinancing into lowerrate mortgages.

To set the stage for my analysis of deleveraging, I begin by examining how some households ended up with so much leverage in the first place. I find that, as of 2007, homeowners in states that had experienced the most pronounced housing booms tended to have considerably more mortgage debt than homeowners in other states. However, even the most indebted 
of these households did not at that time appear excessively leveraged, because they had seen so much home price appreciation. In other words, they appeared to have fairly solid balance sheets under the assumption that home prices would remain flat or increase going forward. In the end, of course, these homeowners were left in a precarious situation when the rise in home prices proved to be a bubble: their mortgages often came to exceed the value of their homes, and they had limited, if any, ability to borrow more, refinance, or sell their homes in the face of a shock to income that made it difficult to make their (relatively high) mortgage payments.

I also find that after the housing bubble burst, highly leveraged households had larger declines in spending than their less leveraged counterparts despite having smaller changes in net worth, suggesting that their leverage weighed on their consumption above and beyond what would have been predicted by wealth effects alone. Results from regressions that control for wealth effects and other factors that might have influenced consumption are consistent with this view. Not surprisingly, highly leveraged mortgage borrowers also had more difficulty meeting their loan payment obligations in the wake of the home price bust, and nearly a fifth of them were no longer homeowners by 2011 .

The most similar study of deleveraging to date is a paper by Atif Mian, Kamalesh Rao, and Amir Sufi (2011), which compares spending patterns across U.S. counties with different average degrees of household leverage. That paper finds that retail sales dropped much more sharply in counties with higher leverage. One challenge in interpreting these results is that the counties with the most leverage also tended to be those with the largest home price declines, such that a powerful wealth effect, in addition to any deleveraging effect, should have been depressing consumption in these areas. My paper goes beyond the Mian, Rao, and Sufi analysis to show that high leverage appears to be associated with weak consumption growth even after accounting for wealth effects.

The limitations of my data source make it difficult to quantify the precise effects of deleveraging on the macroeconomy. However, using data that extend through 2011, I show that U.S. households, on the whole, have made very limited progress in reducing leverage over the past few years. Important financial strains persist, as evidenced by the fact that there was essentially no reduction between 2009 and 2011 in the share of homeowners reporting that they were somewhat or very likely to have problems making their mortgage payments over the coming year. 


\section{Background}

In this section I set the stage for the analysis to come. I discuss the macroeconomic backdrop in order to provide context for why high household leverage is a key policy issue, and I provide more detail about the possible channels through which leverage might be influencing household spending. I also explain how my work fits in with previous studies of household indebtedness.

\section{I.A. The Household Debt Crisis and the Macroeconomy}

The lackluster economic recovery during the past two and a half years has spurred discussion about whether the United States will experience a "lost decade" of stagnant economic growth as Japan did following the bursting of its own property price bubble in the early 1990s. Carmen Reinhart and Kenneth Rogoff (2009) present evidence that the weakness in the U.S. economy is likely to persist for a very long time. Examining a large number of severe financial crises in developed and emerging economies over several centuries, Reinhart and Rogoff document that the economic slumps that follow tend to be deep and protracted. They note that it is "beyond contention that the [recent] U.S. financial crisis [was] severe by any metric" (p. 467), the implication being that the U.S. economy is likely to share a similar fate.

Household debt plays a key role in the narrative supporting this view. Outstanding consumer loans and, especially, residential mortgage loans rose significantly during the credit boom in the early and middle part of the last decade (figure 1). The subsequent sharp increase in the number of households having problems making mortgage payments, which began before the economy fell into recession and joblessness rose, suggests that many households took on more debt during the boom than they could sustain over the long run. Although rapidly rising home prices meant that mortgage leverage — as captured by the aggregate mortgage loan-to-value ratio- barely budged for much of the credit boom, it rose sharply after home prices turned down in mid-2006 (figure 2). Many analysts think that this "debt overhang" and the ensuing process of deleveraging have held back consumption and the broader recovery over the past few years and will remain a headwind against economic growth for some time to come.

It is important to explore the veracity of this narrative. As policymakers gauge whether additional fiscal and monetary stimulus might be justified, they need to understand how the still-elevated level of aggregate household leverage bears on the underlying strength of the economy. Moreover, a better understanding of the implications of high leverage might shed light on 
Figure 1. Aggregate Ratio of Household Debt to Disposable Personal Income, 1980-2011Q4

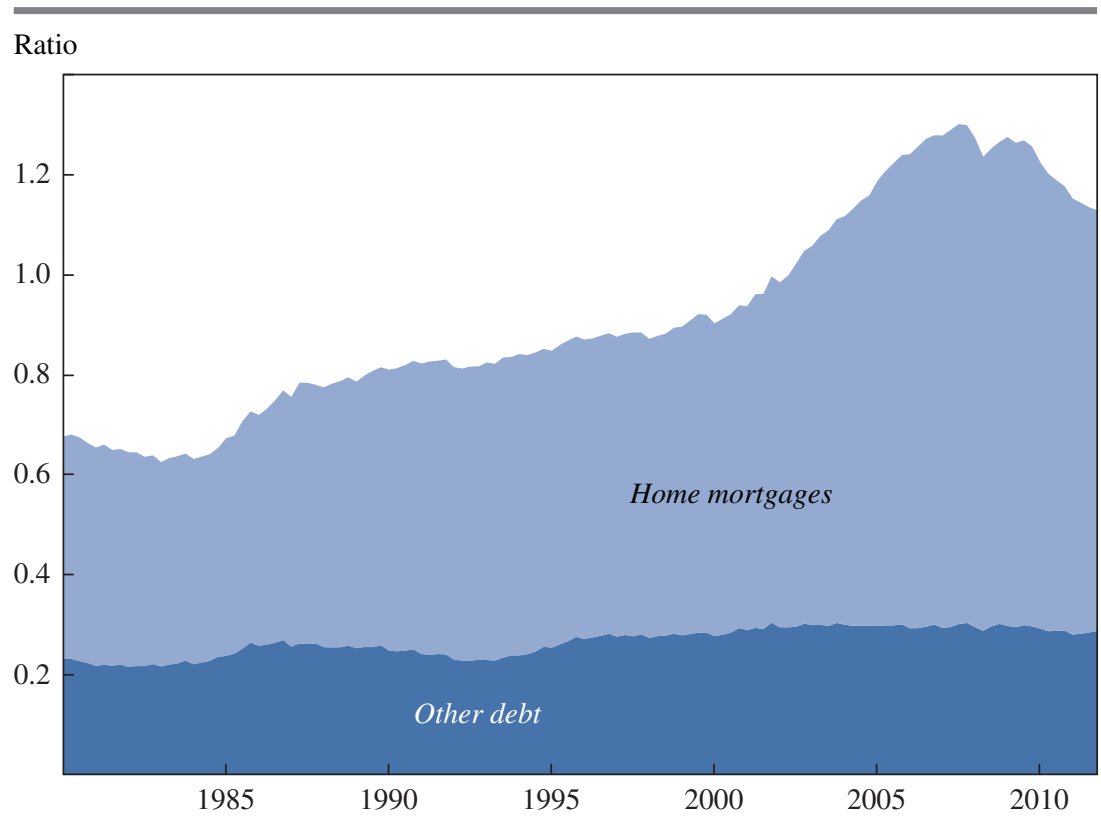

Source: Author's calculations from Flow of Funds (Federal Reserve) data and National Income and Product Accounts (Bureau of Economic Analysis) data.

Figure 2. Aggregate Ratio of Household Mortgage Debt to Home Value, 1980-2011Q4

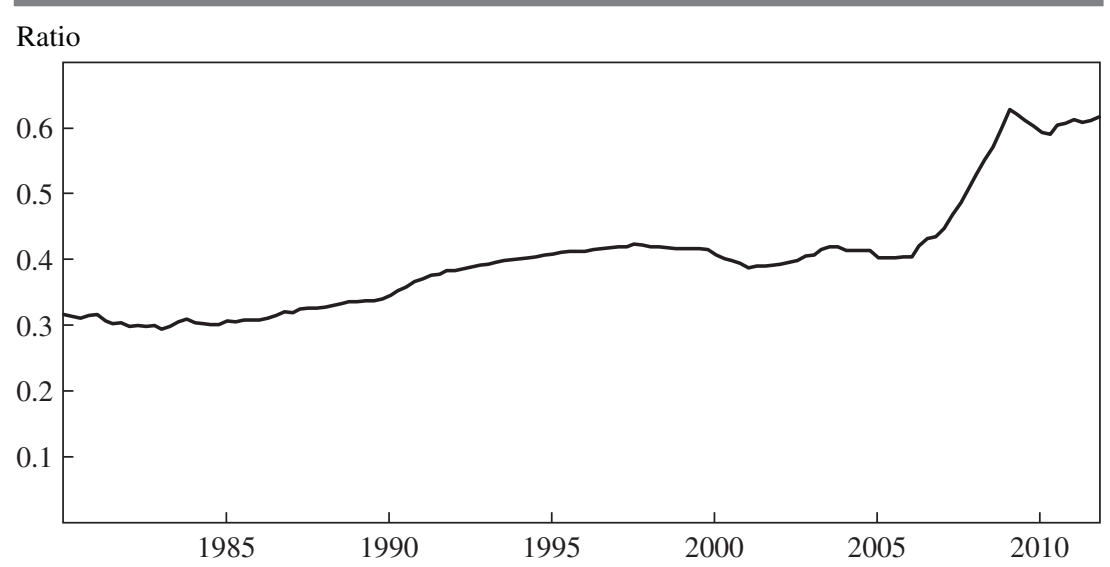

Source: Author's calculations from Flow of Funds data. 
the benefits of specific policy interventions. For example, Joseph Gagnon (2011) and others have argued for improvements in programs that allow "underwater" borrowers (those with mortgages exceeding the value of their homes) to refinance, so that more households can benefit from the low mortgage rates that have resulted from accommodative monetary policy. Other analysts have advocated reducing mortgage principal in order to revive the economy (see, for example, Goodman 2011).

\section{I.B. What Is the Relationship between Household Debt and Spending?}

In the simplest models used by economists, households can borrow as much as they wish, and a household's spending at any given time is based on its expected lifetime resources, interest rates, and tastes. This level of spending, together with the household's current income, determines its current saving or dissaving (borrowing). If incomes are expected to rise over time until retirement, as they typically do, households in this constraintfree world will tend to take on debt, on net, when young, move into positive net worth as they age, and then run down their net worth in retirement. Of course, evidence suggests that in the real world many households cannot borrow as much as they wish. These liquidity-constrained households may at some points in their lives have to accept levels of consumption that are low relative to their lifetime resources.

Even households with positive net worth often choose to hold some debt. This behavior arises in part because of the convenience of using credit cards, but a more important consideration is the need to borrow to purchase a home: when a household wants to own a home, and its desired housing services can only be provided by a property whose value exceeds the household's wealth, borrowing is the only option. In this case, the household not only has a motivation for borrowing but also can use the home as collateral, to create an ability to borrow that would not otherwise exist.

Two factors appear to have been especially important to the rapid growth of U.S. household debt in the early and mid-2000s. First, financial innovation continued to broaden households' access to credit and lower the cost of credit for households that already had access; this process (which had been under way for decades) in some ways accelerated over the period, amid lagging financial regulation (see Dynan 2009). For example, the increasingly popular "nontraditional" mortgages allowed households with lower or more variable incomes, less wealth, and weaker credit records to finance the purchase of a home. Second, and perhaps relatedly, rapid home price appreciation fueled growth in mortgage debt and other household debt. Most notably, higher home prices increased desired spending 
through a wealth effect, and some of that higher spending was financed by borrowing. ${ }^{1}$ Moreover, higher home prices increased the value of collateral against which constrained households could borrow to finance their desired spending.

A household's leverage is often measured by the ratio of its debt to its assets, or, in work focusing on housing, the ratio of a homeowner's mortgage balance to the value of the underlying home. The use of such measures probably reflects in part lenders' emphasis on these ratios when setting the interest rate on loans or determining their willingness to lend in the first place. In any case, such measures are closely related to the traditional leverage ratio of assets to net worth used in the corporate finance literature. If $D$ represents debt, $A$ represents assets, and $N W$ represents net worth, then

$$
\frac{D}{A}=1-\frac{1}{\frac{A}{N W}} .
$$

Economic theory suggests that household spending and balance sheets should have changed in several ways in response to the approximately one-third drop in national-average home prices since their peak in mid2006. The direct effect of this decline was a drop in household assets and net worth with no change in debt, leaving households more leveraged than before. This loss in wealth should have led households to spend less and therefore to save more out of their current income; over time, that higher saving should push net worth back up again. Further, there are two reasons to expect that this rebuilding of wealth following the decline in home prices should have led to lower debt. First, lower household spending —on consumer goods and services as well as homes-would be generally associated with a reduced desire to borrow to finance such spending. Second, homeowners had a reduced capacity to borrow because the decline in home prices means that they had less collateral against which to do so.

The point is that traditional wealth effects alone should have led to an endogenous reduction in debt. Debt also probably fell endogenously for other reasons. In particular, weak income growth as well as uncertainty and pessimism about future income prospects likely damped consumer spending and, in turn, depressed the need to borrow to finance that spending.

1. Although homeowners who experience home price appreciation also experience an increase in their expected future housing costs, they see an increase in their net lifetime resources if they plan to downsize in the future and do not fully internalize any increase in housing costs for their children. 
However, some part of the decline in household debt may have been driven by the high levels of debt, leverage, and debt service themselves. Households that experienced a sharp increase in leverage when home prices declined might simply have been uncomfortable with being so leveraged. Other households may have felt the need to reduce debt because their debt-service obligations increased to unsustainable levels after low, timelimited "teaser" interest rates obtained at the time of mortgage origination expired. When home prices are stable or rising, borrowers with teaser rates can typically refinance into new low-interest-rate loans before the interest rate on the original mortgage increases, but borrowers that fell into negative equity with the recent home price decline would not have been able to do so. Further, households' discomfort with their recent level of leverage and debtservice obligations may have been exacerbated by the heightened probability of job loss; such a dynamic has been formalized recently in a model presented by Christopher Carroll, Jiri Slacalek, and Martin Sommer (2012).

Lenders' behavior - in conjunction with high levels of leverage-may also have contributed to the decline in household debt. Households with high leverage (and high debt-service obligations) generally have more difficulty obtaining loans from financial institutions and have had particular difficulty in recent years because of the sharp tightening of loan standards in the wake of the financial crisis. Although credit conditions have been gradually thawing over the past couple of years, the supply of credit remains considerably more restricted than normal, particularly for mortgages (see Bernanke 2012).

These considerations might help explain both the low levels of new borrowing and (in some cases) the high rate of loan default in recent years. ${ }^{2}$ Further, some of these considerations - if they have weighed heavily enough on households - may have provided an additional motivation to reduce spending and raise saving beyond that related to changes in wealth and the other traditional determinants of consumption. Yet the empirical aggregate consumption functions used by many policy-oriented economists traditionally do not include debt or leverage as an explanatory variable, instead capturing balance sheet considerations solely by including aggregate net worth (see Dynan 2012). It is important to explore, then, whether high debt and leverage might be having an independent influence on consumption, in order to assess whether the traditional approach might be leading analysts seriously astray.

2. See Bhutta (2012), Woodward and Hall (2012), and Dynan (2011) for discussions of how the decline in aggregate debt owes to both depressed new borrowing and high rates of default. 


\section{I.C. Previous Literature}

Relatively little attention was given to household debt issues before the recent crisis. Much of the literature instead focused on whether credit constraints explained the excess sensitivity of aggregate consumption to aggregate income (see, for example, Ludvigson 1999). At the household level, Kathleen Johnson and Geng Li (2007) found that the consumption of households with low liquid assets and high debt-service burdens was more sensitive to changes in income than the consumption of households with low liquid assets alone. There was also some interest in the role of appreciating homes as collateral for borrowing-constrained households, particularly as home prices began to rise rapidly early in the 2000s (see, for example, Iacoviello 2005 and Disney, Bridges, and Gathergood 2010). But some research from previous decades did give heed to the possible role of household debt in economic downturns. For example, Frederic Mishkin (1977) argued that fears of excessive debt-service burdens induced a deleveraging that contributed to the severity of the 1973-75 recession.

Much more research has focused on household debt, particularly mortgages, since the financial crisis. This newer literature includes papers that look at the early rise in defaults among subprime borrowers (Mayer, Pence, and Sherlund 2009), the interplay between the borrower's choice to default and the lender's choice to modify the terms of the mortgage (Foote and others 2009), strategic defaults by underwater borrowers (Bhutta, Dokko, and Shan 2010), and the relationship between defaults and securitization (Keys and others 2010). The research has yielded a number of interesting and important findings.

Nearly all of this more recent work, however, has used mortgage records or credit bureau data. Those data sources have shed light on important issues regarding the crisis, but they have their shortcomings. Most notably, the background information about the debt holders is typically limited to what one would find on a loan application. Researchers have partly mitigated this problem by merging this information with additional data such as average income by zip code, but the potential for such merges is limited, and the information is still not household-specific. An important strength of the household survey data set used in my analysis is that it provides rich background information about the borrowers that I study. ${ }^{3}$

In addition, most of the past work has been backward-looking, aimed at exploring the causes of credit distress. There has been fairly little work that

3. Stafford, Gouskova, and Chen (2012) use data from the same household survey to study the factors that have precipitated mortgage distress in recent years. 
ties credit distress and, especially, deleveraging to economic activity. ${ }^{4}$ Two notable exceptions are papers by Mian and Sufi (2011) and Mian and others (2011), which look at employment and spending patterns in U.S. counties with different degrees of leverage on household balance sheets. One limitation of these papers is that the counties with the most leverage also tend to be the counties with the largest home price declines, such that the degree to which these authors' finding of soft recent economic activity reflects a special deleveraging effect as opposed to traditional wealth effects is unclear.

\section{Data Sources}

Although macroeconomic data have been the basis for much casual analysis of deleveraging, such data have limited value for understanding the true linkages between household debt and consumption. My analysis will rely primarily on the Panel Study of Income Dynamics (PSID), the longestrunning representative longitudinal survey of U.S. households. As I show, the information in the PSID is broadly consistent with macroeconomic developments in recent years. The data set also provides clear evidence of the central role that home prices played in explaining why households accumulated so much debt during the boom.

\section{II.A. The Need to Use Micro Data}

U.S. statistical agencies publish timely estimates of aggregate household debt and related variables at a quarterly frequency. However, these data have limited value for understanding the causes and consequences of the household debt crisis. In particular, the aggregate measures may not adequately capture important debt-related pressures in subgroups of the population. For example, the 2002-06 increase in aggregate household debt shown in figure 1, although more concentrated over time, was no larger in magnitude than the rise over the preceding two decades, which did not have particularly pernicious consequences. Indeed, the earlier rise in debt likely benefited households by allowing them to better smooth their consumption over the business cycle and over the life cycle. A key difference between the rise in debt in the early to mid-2000s and that in earlier decades was that the latter was fairly spread out across the population (Dynan 2009), whereas the former saw concentrations of households taking on very large amounts

4. Another strand of more forward-looking work considers how households are adjusting their balance sheets as they deleverage. See Brown and others (2011) and Bricker and others (2011). 
Figure 3. Personal Saving Rate, 1980-2012Q1

Percent of disposable personal income

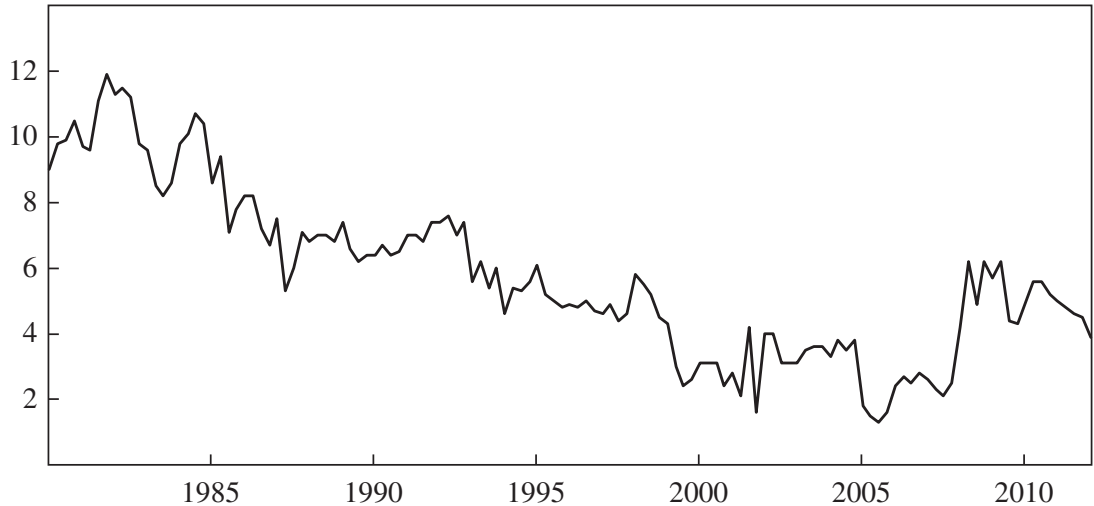

Source: National Income and Product Accounts data.

of debt (see, for example, Mayer and others 2009). Because the aggregate data essentially masked this trend, policy analysts who took the traditional approach of focusing on aggregate measures greatly underestimated the amount of risk building up in the financial system before the crisis.

Looking beyond the aggregate data is likely to be equally important in assessing the nature and implications of the deleveraging that has occurred since the bursting of the credit bubble. For example, the recent behavior of the aggregate personal saving rate might suggest that deleveraging is not an important force holding back consumer spending. The saving rate has, in fact, risen in recent years, from just below $1 \frac{1}{2}$ percent at its low point in 2005 to an average of $4 \frac{1}{2}$ percent over the past year (figure 3 ). But given the conventional wisdom that the marginal propensity to consume out of wealth is between 3 and 6 cents on the dollar (see, for example, Davis and Palumbo 2001), the decline in household net worth alone would predict an increase in the saving rate on the order of 4 to 8 percentage points-much higher than the realized increase. Absent other factors, deleveraging, if important, should have raised the saving rate yet further. Accordingly, skeptics argue that the observed rise in the saving rate is too small for deleveraging to have been an important force.

The problem with such arguments is that many factors are currently affecting consumption and saving, some of which—including low interest rates and consumption smoothing in the face of transitory disruptions to income-are 
probably boosting consumption and reducing saving. ${ }^{5}$ Aggregate data likely offer too little variation to identify any independent effect that deleveraging might have had on consumer spending. In addition, because aggregate data do not provide a good picture of the financial situation of the mostindebted households, they also cannot tell us how much more deleveraging is to come. Given the importance of these issues for the prospects of the U.S. economy, it is essential to study deleveraging with household-level data.

\section{II.B. The Panel Study of Income Dynamics}

This paper uses household survey data from the PSID to examine the household-level underpinnings of the run-up in borrowing in the 2000s and the subsequent deleveraging. This survey collects a rich set of background information from its participants that can shed light both on what led some households into such precarious financial positions and on what, if anything, they have done subsequently to reduce debt and rebuild their net worth. The resulting findings are thus a complement to the existing body of micro data-based research on the mortgage crisis, nearly all of which is based on administrative financial data records where the background information is largely restricted to what is on a loan application.

Launched in 1968, the PSID is a panel survey of households conducted by the Institute for Social Research at the University of Michigan. Participating households were at first surveyed every year, but beginning with the 1997 wave, the frequency was changed to every other year. The most recently released full wave contains information from about 8,000 interviews conducted in 2009. In February 2012 a very limited set of preliminary data from the 2011 wave of the PSID was released, including the information needed to construct net worth as well as the results from a special module on foreclosures and mortgage payment problems. The survey's documentation cautions that these data are subject to revision, but given the importance of using timely information for the questions at hand, I make use of them in the analysis below.

The PSID contains fairly extensive information about mortgages on primary residences as well as loans used to finance motor vehicle purchases. Balances on other common types of household debt—-such as credit cards, student loans, medical and legal bills, and loans from relatives—were reported

5. Another factor that might be coming into play is the distribution of income. Using data from tax returns, Saez (2012) showed that the share of income going to the top decile fell, on net, between 2007 and 2010 (taking back a small portion of the substantial rise seen since the early 1980s). Because high-income households tend to have higher saving rates, this trend would tend to raise consumption and lower the aggregate saving rate. 
as a group until 2011, when the questionnaire was changed to collect more detail. ${ }^{6}$ The PSID also provides some information about assets and about net equity in businesses, vehicles, and second homes, so that one can create a limited measure of households' net worth. ${ }^{7}$ Data on expenditures on food and a few other items are available for most waves of the survey; questions about many more categories of spending were added between 1999 and 2005, such that a broad (although still not complete) measure of consumption can be constructed for the 2005, 2007, and 2009 waves. The special module on foreclosures and mortgage payment problems first appeared in the 2009 survey.

I calculate the mortgage debt of each household as the sum of the balances of any first and second mortgages on its primary residence. I calculate consumer debt as the sum of outstanding balances on up to three vehicle loans (backed out from information on the original balance of the loans and the payment history) plus the reported sum of balances on other types of consumer loans. Debt-service obligations are derived from information on required loan payments, except for the "other loan" category, where, because much of this debt is presumably credit card debt, I follow the Federal Reserve's convention of assuming that the required monthly payment is 2.5 percent of the balance. ${ }^{8}$ I calculate the net worth of each household as the sum of the values of its primary residence, its private annuities and individual retirement accounts, any other stocks or bonds or mutual funds, its bank accounts, and its net equity in businesses, vehicles, and second homes, minus the household's mortgage debt and its non-vehicle-related consumer debt.

For my income measure I use total family income before taxes, as information about after-tax income is not available. I set nonhousing consumption equal to the sum of spending on vehicles, vehicle-related items, gasoline, transportation, furniture, clothing, tuition, other school-related items, and food (both at home and away from home). One complication is that the time period over which the expenditures are supposed to be reported varies by category, from "an average week" to the previous month to the previous year. In constructing my nonhousing consumption measure,

6. I aggregate the more detailed 2011 information such that for each household I have a total nonmortgage debt figure that is conceptually equivalent to that provided in earlier waves. In principle, there is no reason to expect an important series break, but, of course, one always needs to use caution in interpreting patterns when survey questionnaires change.

7. The survey asks for very little information about pensions and retirement saving. It also excludes some more unusual types of assets and liabilities.

8. See "Household Debt Service and Financial Obligations Ratios" (www.federalreserve. gov/releases/housedebt/about.htm). 
I adjust spending for all of the components to be on an annual basis and add them together, essentially ignoring the time mismatch. ${ }^{9}$

I augment the PSID data with state-level information in order to better capture the macroeconomic conditions faced by each household. Specifically, I add state unemployment rates as well as indexes of state home prices produced by CoreLogic, a private firm that collects and distributes consumer, financial, and property information.

One long-standing issue confronting researchers using household-level wealth data is the treatment of outliers. The distribution of wealth in the United States is highly skewed, with a long right tail. As a result, extreme values will tend to have an undue influence on means and on results from ordinary least squares regressions. Measurement error in wealth data and small sample sizes further reduce the usefulness of such analyses. For these reasons I focus mainly on medians in the analysis of summary statistics below and apply a transformation that downweights the influence of outliers in the regression analysis.

The calculations presented throughout the paper are based on weighting the PSID observations. I use the longitudinal weights provided by the PSID for the core sample of households combined with the additional sample of immigrant families.

\section{II.C. Summary Statistics on Household Balance Sheets and Consumption}

Table 1 reports some summary statistics for the households in the sample. All responding households from each wave are included, although for some variables, such as consumption and net worth, some observations are missing because the household did not report full data for the variable or its components. As discussed above, I show medians instead of means so as to avoid the influence of unduly large readings, particularly for balance sheet variables. Accordingly, the results describe the experience of the typical household rather than the average household. Although the means, in principle, might be more telling about aggregate conditions, they are unlikely to be representative given the relatively small numbers of wealthy households in the PSID sample. ${ }^{10}$

9. The exception is vehicle expenses, for which I include unannualized spending for the year to date. An alternative would be to use spending for the previous calendar year, but that choice would have made the data less timely and thus less useful in identifying any recent effects of deleveraging.

10. For precisely these reasons, the Survey of Consumer Finances, which is viewed as the most representative of U.S. household wealth surveys, oversamples rich households. 
Table 1. Summary Statistics for PSID Households ${ }^{a}$

\begin{tabular}{lccr}
\hline Statistic & 2005 & 2007 & 2009 \\
\hline Median values for all households & \multicolumn{3}{c}{ Dollars (nominal) } \\
Family income (pretax, previous year) & 45,180 & 49,000 & 50,504 \\
Nonhousing consumption & 15,548 & 16,560 & 15,280 \\
Net worth & 57,000 & 66,000 & 41,000 \\
Share of all households holding & & Percent & \\
Home & 65.1 & 64.1 & 61.9 \\
Mortgage debt & 43.9 & 43.1 & 42.3 \\
Vehicle debt & 37.2 & 40.0 & 38.0 \\
Other debt & 50.7 & 50.6 & 51.1 \\
Median values for households holding & \multicolumn{3}{c}{ Dollars (nominal) } \\
Home & 170,000 & 200,000 & 180,000 \\
Mortgage debt & 98,000 & 110,000 & 118,400 \\
Vehicle debt & 10,249 & 10,141 & 9,895 \\
Other debt & 6,000 & 8,000 & 8,200 \\
No. of observations & 8,002 & 8,289 & 8,690 \\
\hline
\end{tabular}

Source: Author's calculations using PSID data.

a. Calculations are weighted using the longitudinal weights provided by the PSID. All responding households from each wave are used, although for some variables, such as consumption, net worth, and vehicle debt, some observations are missing because the household did not report full data for the variable or its components.

The movements in the variables between waves of the PSID are broadly consistent with other information on economic developments in recent years. Median pretax family income rose between the 2005 and 2007 waves, corresponding to an increase in income between calendar years 2004 and 2006, and rose again (modestly) between the 2007 and 2009 waves, corresponding to calendar 2006 and 2008; aggregate personal income, as published in the National Income and Product Accounts (NIPA, not shown in the table), also rose over both time spans. ${ }^{11}$ Median nonhousing consumption rose between 2005 and 2007 but reversed that gain between 2007 and 2009, falling 8 percent; aggregate NIPA consumption (not shown) also rose between 2005 and 2007 and then edged down between 2007 and 2009. The larger decline seen in PSID consumption may reflect the fact that the median household did worse than the average household during the recession; it may also reflect the fact that my measure excludes less discretionary items such as payments for utilities and health care. Median net worth rose considerably between 2005 and 2007 but plunged over the next 2 years;

11. Even though the recession began in December 2007, the first annual decline in NIPA personal income was between calendar 2008 and 2009. 
aggregate household net worth, as published in the Federal Reserve's Flow of Funds Accounts (not shown), showed the same general pattern, but with less pronounced changes.

The homeownership rate in the PSID sample fell between 2005 and 2007, and again between 2007 and 2009. The median reported home value rose 18 percent between 2005 and 2007 and then reversed two-thirds of that gain between 2007 and 2009. Although this pattern is consistent with households recognizing a boom and bust in home prices, the timing differs from that seen in direct data on home prices. The CoreLogic national index of home prices peaked in April 2006 and by mid-2007 was just 2 percent above its reading 2 years earlier. Between mid-2007 and mid-2009, the CoreLogic index declined 24 percent. At face value this comparison suggests that households adjust their views of the values of their homes with a lag, or perhaps are too optimistic in general. However, a more complete analysis is needed before one can draw strong conclusions. ${ }^{12}$

The credit cycle seen in aggregate data appears to some extent in the PSID data as well. The fractions of households in this sample holding mortgage debt and vehicle debt fell between 2007 and 2009. Median vehicle debt for households holding such debt also declined between 2007 and 2009, but median mortgage debt for households with mortgage debt increased over that period. The latter pattern may reflect new homeowners, who tend to purchase smaller homes, being shut out of the market—indeed, Neil Bhutta (2012) concludes that first-time homebuying has been very weak, especially for households with less-than-excellent credit scores. It may also reflect the possibility that the credit crunch was felt mostly in the tails of the household indebtedness distribution, at least at the beginning.

The table also shows some clear limitations of the data. In particular, the fraction of households holding mortgages, at just over 40 percent, is considerably below the roughly 50 percent figure that shows up in the Federal Reserve's Survey of Consumer Finances (SCF), which is widely considered to have the best available data on U.S. household balance sheets. Moreover, median net worth is only about half as large as in the SCF. The latter discrepancy likely owes in large part to the fact that the PSID collects data on only a limited part of total household wealth. Indeed, Barry Bosworth and Rosanna Smart (2009) present a thorough comparison of the PSID and the SCF and conclude that, once put on a comparable basis,

12. Since the findings in this paper are based on what households perceive their home values to be, they may be more telling about household behavior than results based on actual home value data. On the other hand, the findings here may be less useful for macroeconomic forecasters who base their outlook on actual home values. 
the wealth measures in the two surveys are very similar through the 95th percentile of the wealth distribution.

Another issue raised by table 1 is that median nonhousing consumption seems low relative to median pretax income. Again, the explanation may be the limited scope of the questions. Li and others (2010) find that the information from many of the consumption categories added since 1999 compares favorably with estimates from the Consumer Expenditure Survey. In any event, to the extent that the movements in these partial measures are correlated with movements in more comprehensive measures, the results presented below should generalize to consumption as a whole.

\section{II.D. Household Debt and Spending during the Credit Boom}

To lay the groundwork for the analysis of deleveraging, I examine households' experience in the period leading up to the crisis, so as to shed more light on why households accumulated so much debt during the boom. Table 2 compares households in the top quintile of leverage as of 2007 with those with lower leverage. Given that rapidly rising home prices in some parts of the country were thought to have been a key precipitating factor for the credit crisis, I divide households into three groups that might be expected to have very different responses to this trend: nonhomeowners, homeowners residing in states in the top quartile of home price appreciation between 2000 and 2006 (henceforth called "boom states"), and homeowners residing in other states ("non-boom states"). ${ }^{13}$ Households with retired heads are excluded from the comparison because I normalize some variables by current household income, which is often hard to interpret for retirees. The sample is also restricted to households that had a complete set of interviews for the 2005, 2007, and 2009 waves of the PSID.

PRECRISIS PATTERNS OF LEVERAGE AMONG NONHOMEOWNERS The first two columns of table 2 present estimates for nonhomeowners. For this group I define leverage as total debt-which effectively means consumer debt such as auto loans, credit card balances, and student loans-divided by total assets. The median amount of consumer debt for highly leveraged nonhomeowners in 2007 was $\$ 20,000$, whereas the median for other nonhomeowners was zero. Along many other dimensions, the two groups summarized in the first two columns look fairly similar. For example, median levels of pretax income and nonhousing consumption in 2007 were about the same, and both groups had a few hundred dollars of financial assets at

13. By this measure, the states with home price booms were Arizona, California, Connecticut, the District of Columbia, Florida, Hawaii, Maryland, Nevada, New Jersey, New York, Rhode Island, and Virginia. 


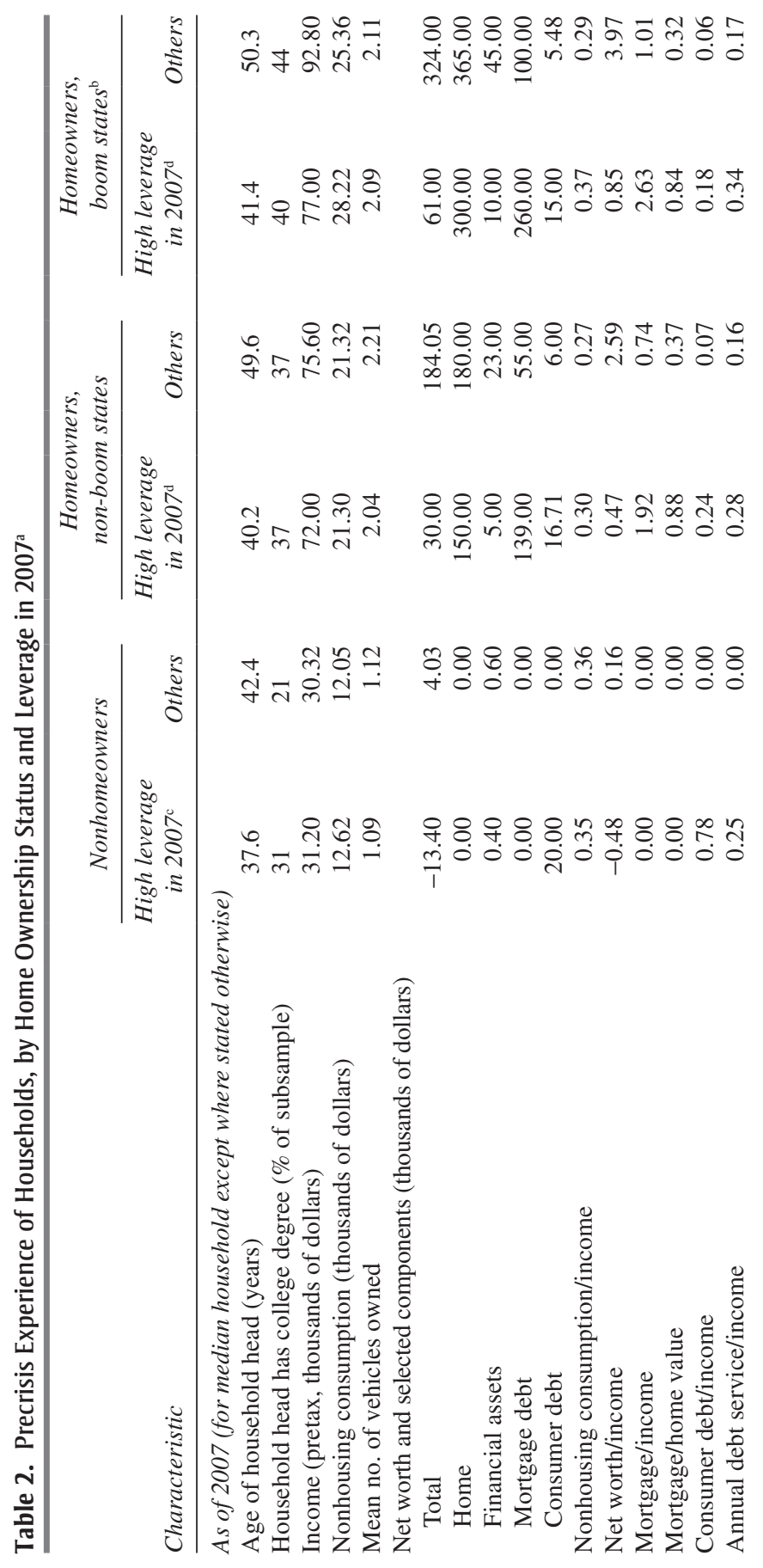




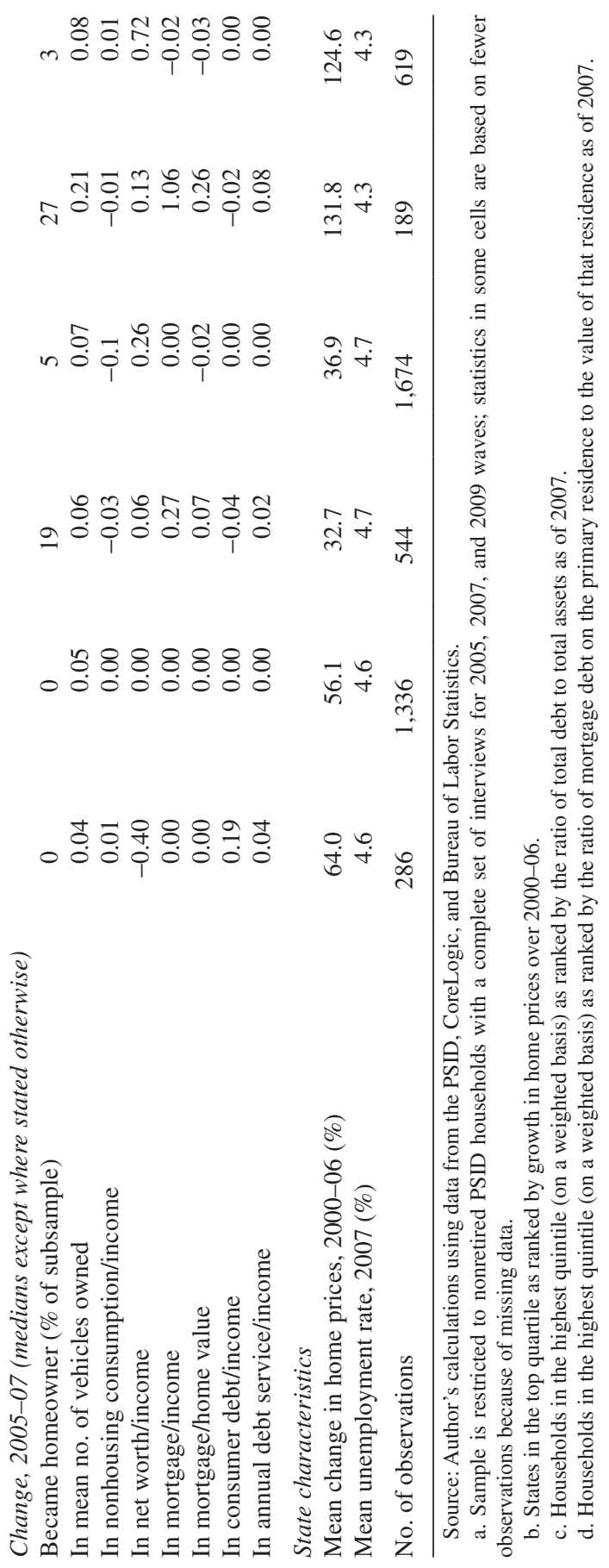


the median. Given that the increase between 2005 and 2007 in the median ratio of consumer debt to income (middle panel of table 2) for the highly indebted group was only about one-quarter as large as the median 2007 ratio, it appears that many of the highly indebted have been so for a while. This result could indicate a chronic shortfall of self-control by some households, but it could also reflect fully rational behavior for households that expect their income to be much higher in the future because, for example, the household's primary earner works in a profession where income rises sharply with job tenure. Note that highly indebted nonhomeowners are considerably more likely to have a college degree than other nonhomeowners. More education might increase the use of credit by this group in two ways: first, because it is associated with greater access to credit, and second, because people with more education tend to have steeper age-income profiles, perhaps leading them to smooth their consumption by taking on large amounts of debt early in their careers.

PRECRISIS PATTERNS OF LEVERAGE AMONG HOMEOWNERS LIVING IN NON-BOOM STATES The third and fourth columns of table 2 correspond to homeowners living in states outside the top quartile of states ranked by home price appreciation during the boom. For all homeowners I define leverage as mortgage debt for the household's primary residence divided by the value of that residence, all as of 2007. Using this more restricted measure of leverage allows me to retain more households for the analysis, as there are many cases where full data on other types of assets and liabilities are not available. ${ }^{14}$ Highly leveraged homeowners in non-boom states tended to be younger and to have (slightly) lower income and smaller homes than other homeowners in those states. At the median in these states, the consumption of the highly leveraged homeowners was a little higher relative to income than the consumption of other homeowners. Both the mortgage debt and the consumer debt of the highly leveraged group were considerably higher than those of other homeowners: at the median, their mortgage debt amounted to nearly 2 years' worth of income versus 8 months for less leveraged homeowners. For the highly leveraged homeowners, monthly debt obligations represented 28 percent of pretax income at the median, and roughly a fifth of them had become homeowners sometime in the preceding 2 years.

Relative to 2 years earlier, the homeowners in these non-boom states who were not highly leveraged seem to have been in a stronger financial position, with no increase in debt and an increase in median net worth of

14. The results are not sensitive to this choice, which is not surprising given that housing assets and liabilities dominate the balance sheets of most homeowners in the PSID. 
26 percent of annual income. In contrast, the highly leveraged group experienced an increase in mortgage debt exceeding 3 months' worth of income at the median. Even for this group, however, the median ratio of net worth to income increased between 2005 and 2007, and the median ratio of consumer debt to income edged down.

PRECRISIS PATTERNS OF LEVERAGE AMONG HOMEOWNERS LIVING IN BOOM STATES The most striking comparison in table 2 is that between highly leveraged homeowners and other homeowners in the states with the largest housing booms, shown in the fifth and sixth columns. The highly leveraged households again tended to be younger, but they had considerably less pretax income at the median than households in the same group of states who were not highly indebted $(\$ 77,000$ versus $\$ 93,000)$. Yet median nonhousing consumption for the highly leveraged households was somewhat higher (about $\$ 28,000$ versus about $\$ 25,000$ for other households). For both groups of households in these states, housing was a much more important part of the balance sheet than in states that saw lower rates of home price appreciation: median mortgage debt and home values in the fifth and sixth columns are about double the corresponding figures in the third and fourth columns.

Mortgage debt among highly leveraged homeowners in boom states grew sharply between 2005 and 2007, by an amount exceeding a year's worth of income at the median. In part, this pattern reflects new homeowners entering a housing market that was increasingly expensive. However, new homeowners (those who had purchased their homes since 2005) represented only a little more than a quarter of the highly leveraged households in the boom states. The remaining highly leveraged households likely increased their mortgage leverage by extracting equity through home equity lines of credit, by exchanging smaller mortgages for larger ones in "cashout" refinancing transactions, and by taking on larger mortgages as they turned one home over for the next. ${ }^{15}$

Despite this increase in mortgage debt, the 2007 financial positions of highly indebted households in housing boom states likely seemed solid to those who did not anticipate the housing bust: median net worth had risen by 13 percent of income over the preceding 2 years, and the median ratio of mortgage balance to home value was 0.84 . Note, however, that the typical highly indebted household in a boom state in 2007 had few financial assets compared with other households in those states, and their debt-service obligations amounted to 34 percent of pretax income in 2007-much higher

15. Greenspan and Kennedy (2007) estimated that those forms of home equity extraction accounted for about four-fifths of the rise in home mortgage debt since 1990. 
than for households with less debt and for highly indebted households in non-boom states. Such a household would likely have trouble making mortgage payments if faced with an unanticipated disruption to income, but appeared to have a sufficient equity cushion to sell the home and pay off the mortgage should such a shock occur.

In boom states, the highly leveraged homeowners were slightly less likely to have a college degree than those with less debt-in contrast with the pattern for homeowners in other states and for nonhomeowners. ${ }^{16}$ To the extent that less educated households are more likely to be lured into taking on precariously high levels of debt because of a lack of financial sophistication, one would expect the difference in median education between highly leveraged households and others to be the same for homeowners in boom and non-boom states and for homeowners and nonhomeowners (all else equal). However, credit access was probably higher for homeowners in boom states than for other people, because lenders believed that continued rapid home price appreciation would make it easier for households to meet their debt obligations. Together with a lack of financial sophistication on the part of less educated people on average, this effect would produce the pattern observed in these data.

THE RELATIONSHIP BETWEEN MORTGAGE LEVERAGE AND HOME PRICE APPRECIATION ACROSS STATES As already noted, the results in table 2 suggest that homeowners who did not expect home prices to fall sharply may have viewed themselves as in a fairly solid financial position as of 2007. Even the highly leveraged homeowners in states that had seen the largest home price booms appeared to be in decent financial shape under this assumption. Expectations of stable home prices, or perhaps even further appreciation, may well explain why those homeowners ended up having relatively high consumption and debt-service obligations, as well as low levels of financial assets. However, a cross-state analysis of leverage and home price appreciation illustrates that the financial situation of many homeowners would take a dramatic turn for the worse if home prices were to take back some of their earlier gains.

The three left-hand panels of figure 4 show actual 2007 mortgage leverage at various points in the distribution of households by leverage (median, 80th percentile, and 90th percentile) in different states, plotted against earlier home price appreciation in that state. The size of the circle corresponds to

16. The difference is even larger if one separates households according to who took on the most leverage over the past 2 years. In boom states, 37 percent of the top quintile of households ranked by their change in leverage had a college degree, compared with 45 percent of other households. 
Figure 4. Mortgage Leverage, 2007, and Average Home Price Appreciation, 2000-06, by State, Actual and Counterfactual Scenario ${ }^{\mathrm{a}}$

Median household, actual

Ratio of mortgage debt to home value, 2007

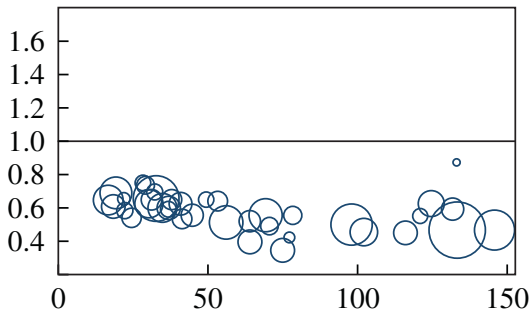

Percent change in average home price in state of residence, 2000-06

80th-percentile household, actual

Ratio of mortgage debt to home value, 2007

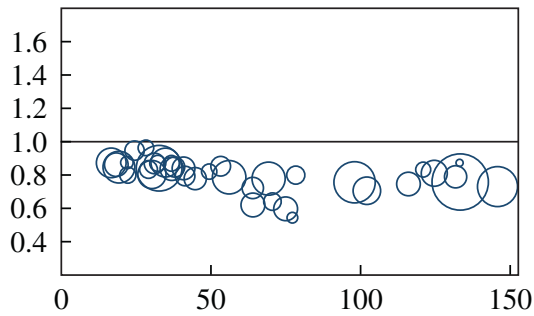

Percent change in average home price in state of residence, 2000-06

\section{0th-percentile household, actual}

Ratio of mortgage debt to home value, 2007

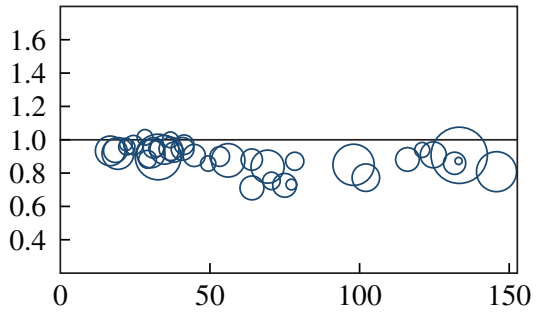

Percent change in average home price in state of residence, 2000-06
Median household, counterfactual

Ratio of mortgage debt to home value, $2007^{\text {b }}$

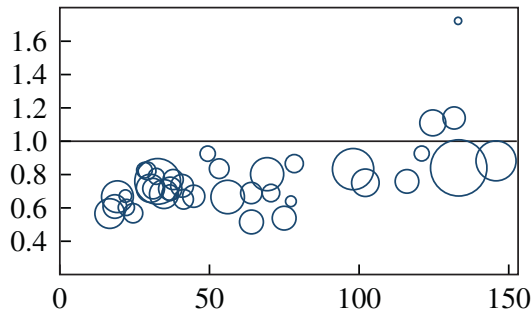

Percent change in average home price in state of residence, 2000-06

80th-percentile household, counterfactual

Ratio of mortgage debt to home value, $2007^{\mathrm{b}}$

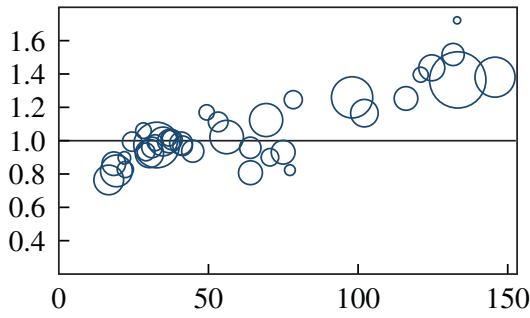

Percent change in average home price in state of residence, 2000-06

\section{0th-percentile household,} counterfactual

Ratio of mortgage debt to home value, $2007^{\mathrm{b}}$

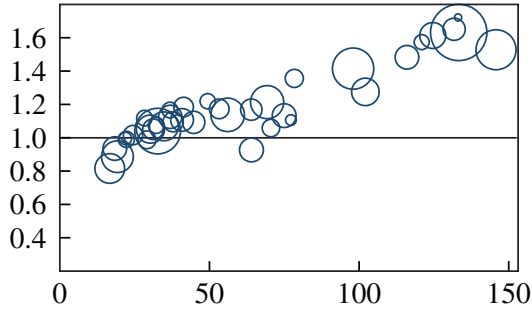

Percent change in average home price in state of residence, 2000-06

Source: Author's calculations from PSID and CoreLogic data.

a. Each circle represents one state; areas are proportional to state population. States with fewer than 30 observations are omitted.

b. The numerator is the actual mortgage balance in 2007; the denominator is the estimated value of the home in 2000 times the increase in nonhousing consumer prices from 2000 to 2007. 
the state's population. I drop states for which I have 30 or fewer observations on the view that these results are less likely to be representative.

These three panels show a slightly negative relationship between actual mortgage leverage in 2007 and earlier home price appreciation. In other words, excessive mortgage debt appeared to be less of a problem in states that had experienced more pronounced housing booms. Indeed, in all but three of the states that saw home prices increase by more than 50 percent between 2000 and 2006, homeowners at the 90th percentile of reported leverage would have been able to withstand a 10 percent decline in the value of their home without going underwater.

The three right-hand panels of figure 4 show what the patterns would likely have been in 2007 if home prices, after rising as they did from 2000 through 2006, had then fallen back to where they would have been had they risen only at the rate of consumer nonhousing inflation from 2000 onward. The numerator of this counterfactual loan-to-value ratio remains the 2007 level of mortgage debt. To construct the denominator, I first estimated what the value of each household's home would have been in 2000 if its appreciation between 2000 and 2007 had matched state-average home price appreciation, and then increased the estimated 2000 home value by the rate at which the "all items less shelter" component of the national consumer price index grew between 2000 and 2007. As can be seen, these counterfactual measures of leverage not only are much higher, but also increase strongly with the size of the home price boom in each state, particularly at the upper end of the distribution. Homeowners above the 90th percentile of leverage would have been underwater in most states and would have had leverage ratios exceeding 1.5 in 15 percent of the states.

All told, the results in this section show that the rise in household debt was concentrated both geographically and, within geographic areas, among a subset of homeowners. The rapid rate of home price appreciation in some parts of the country appears to have been centrally related to this increase in debt. The results are also consistent with the view that the most-indebted households may have ended up in a vulnerable situation because they did not appreciate the risk that home prices might take back some of their earlier gains.

\section{Deleveraging and Its Consequences}

I now turn to the question of what happened to highly leveraged households following the financial crisis and the onset of the recession. I begin by exploring how summary statistics for highly leveraged households com- 
pare with those for households with less leverage, and then formalize the results with regression analysis.

\section{III.A. The Postcrisis Experience of Highly Leveraged Households}

The households in each column of table 3 are the same as those in the corresponding column in table 2 . Households that were highly leveraged in 2007 are again compared with households that had less leverage in 2007, and I again show separate comparisons for nonhomeowners, homeowners in states that were in the top quartile of home price appreciation during the housing boom, and homeowners in other states, all as of 2007.

The top panel of the table shows the changes experienced by the different groups of households between the 2007 and the 2009 waves of the PSID. One feature that stands out is the greater decline in nonhousing consumption seen by the highly leveraged homeowners relative to their counterparts with less debt. This pattern is particularly evident in the housing boom states, where the consumption of the median household in the highly leveraged group fell by almost 15 percent-about twice as much as the median for other households. Notably, these larger declines occurred despite the highly leveraged homeowners seeing more income growth and smaller wealth losses than the less leveraged homeowners.

A more refined take on the question comes from comparing the relative movements of the ratios of nonhousing consumption $(C)$ and net worth $(W)$ to income $(Y)$-the rows shown in italic. For the less leveraged homeowners in housing boom states, at the median, $C / Y$ declined by 0.04 and $W / Y$ declined by 0.83 . These figures suggest a marginal propensity to consume out of housing wealth of $0.04 / 0.83=0.05$, in line with the estimates often cited by analysts and policymakers. For highly leveraged homeowners in housing boom states, conventional wealth effects would imply a decline in $C / Y$ equal to the loss in wealth $(0.67)$ multiplied by a typical estimate of the marginal propensity to consume out of housing wealth (0.05), or 0.03 . But in fact, the median $C / Y$ of these households declined by 0.07 . It would thus appear that high mortgage loan-to-value ratios might have an additional, independent damping effect on consumption. To draw strong conclusions on this point, however, one should control for the various ways in which households that have a lot of leverage might be different from other households; I do so in the next section using regression analysis.

The results in the second panel of the table speak to how mortgage payment problems varied with 2007 leverage. Not surprisingly, highly leveraged households were much more likely by 2009 to have had problems or 


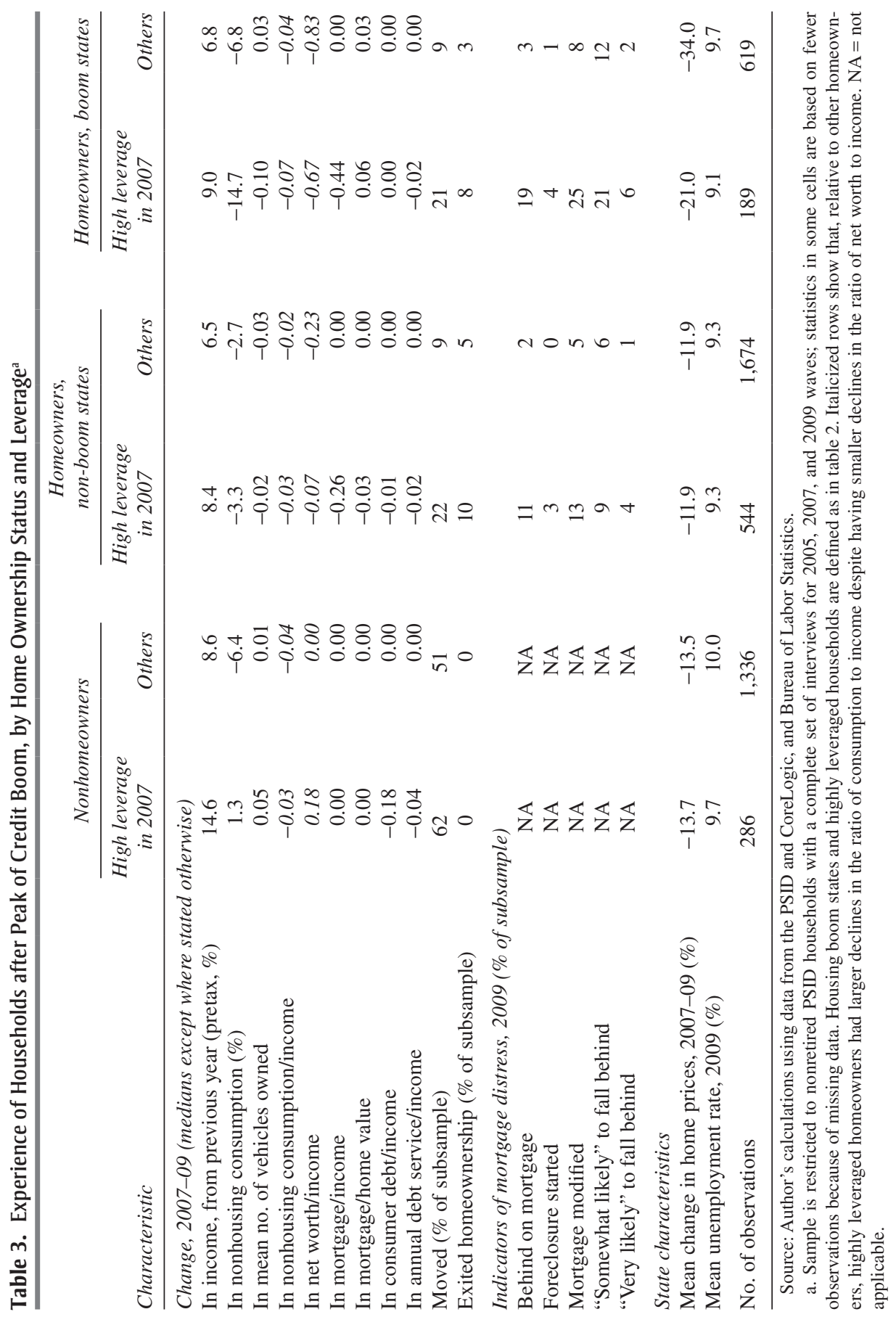


to anticipate having problems making their mortgage payments: in housing boom states, 19 percent of such homeowners were behind on their mortgage payments, versus 3 percent of other homeowners in those states. The comparable figures for states that saw less home price appreciation during the boom were 11 percent and 2 percent. Highly indebted households were also more likely to have experienced a foreclosure filing, to have had their mortgage modified, and to report being very or somewhat likely to fall behind on their mortgage payments over the coming year. In both boom states and non-boom states, more than a fifth of highly leveraged homeowners as of 2007 moved between 2007 and 2009, more than double the rate for homeowners with less leverage; 8 and 10 percent of highly leveraged homeowners in boom and non-boom states, respectively, had exited homeownership altogether. These figures suggest that an important way by which some highly indebted households reduced their debt was by downsizing or defaulting.

I noted earlier that, for some households, the strains of a heavy debt burden may manifest themselves primarily through high debt-service obligations relative to their incomes. In a similar analysis comparing such homeowners with other homeowners (results not shown), I found that the former also saw more pronounced declines in their consumption between 2007 and 2009. The prevalence of mortgage payment problems was the same or lower for households with high debt-service burdens as for highly leveraged households. However, households with high debt service in boom states seemed more likely to anticipate distress than households with high mortgage-to-home value ratios: nearly a third of the former reported being somewhat or very likely to fall behind on their mortgage payments over the coming year.

\section{III.B. Formalizing the Results}

The central question of interest is whether the overhang of housing debt is holding back consumption growth. In particular, I seek to answer whether consumption has shown more weakness than would be expected given the movements in its other fundamental determinants, including the loss in wealth, weak income, and pessimism or uncertainty about future income. The italicized results in table 3 support the notion that excessive leverage has had an important additional depressing effect on the consumption of some households. In this section I test the hypothesis more formally using regression analysis.

Section I.A reviewed the traditional determinants of consumer spending and highlighted why debt, leverage, and perhaps debt-service obligations 
might have an independent influence on spending. All told, those considerations suggest estimating the following equation:

$$
\begin{aligned}
\Delta C_{i t}= & \alpha+\beta_{w} \Delta W_{i t}+\beta_{Y} \Delta Y_{i t}+\beta_{\mathrm{lev}}\left(\frac{D}{A}\right)_{i, t-1} \\
& +\beta_{\mathrm{dsr}}\left(\frac{D S}{Y}\right)_{i, t-1}+\gamma X_{i t}+\varepsilon_{i t},
\end{aligned}
$$

where $\Delta C_{i t}$ is the change in the consumption of household $i$ in period $t$, $\Delta W_{i t}$ is the change in its wealth, $\Delta Y_{i t}$ is the change in its current income (relevant for households that are liquidity constrained or myopic), $(D / A)_{i, t-1}$ is its leverage in the preceding period, and $(D S / Y)_{i, t-1}$ is the fraction of its income going toward debt-service payments in that period. $X_{i t}$ is a vector of other variables that might influence household consumption growth, such as the interest rate, economic conditions in the state, and demographic factors (which might be correlated with time preference, the risk of job loss, and revisions to expected future income). As in table 3, the changes represent differences between the 2007 and 2009 waves of the PSID. Both leverage and debt service are measured as of the beginning of the period over which the change is calculated, because presumably it is the household's ex ante level of balance sheet distress that is relevant for its consumption. If the debt overhang did hold back consumption growth between 2007 and 2009 above and beyond what would be typical given movements in the other determinants of consumption, one would expect to see negative coefficients on the debt-related variables.

Several complications present themselves. First, there are models that could produce a negative $\beta_{\text {lev }}$ or $\beta_{\mathrm{dsr}}$ even in the absence of a separate channel related to the degree of leverage or debt burden. Most notably, if time preference rates vary across households, marginal propensities to consume might tend to be higher for low-wealth households because these households are likely to be more impatient. In this case one would expect low-wealth homeowners to show a larger consumption response to the home price bust. Since debt and, especially, leverage are highly correlated with wealth, the coefficients on these variables would then be biased downward. To shed light on whether my results are being biased by such effects, I also estimate regressions for the period 2005-07. Given that home prices rose, on net, over this period, one would expect to see positive coefficients on the debt variables in these specifications if households with low wealth simply have higher marginal propensities to consume; if the coefficients continue to be negative, the results are consistent with the view that high debt tends to damp consumption. 
Second, the timing of the data is not ideal for estimating equation 2 . Although home prices at the national level had been falling for about a year by the time the 2007 wave of the PSID was launched, they continued to decline rapidly for much of the period between the 2007 and 2009 waves. As a result, the ex ante measures likely understate the degree of debt overhang that may have induced some households to pare back their consumption between 2007 and 2009. However, it is undesirable to simply use ex post (2009) levels of debt variables in the regression: these levels may be correlated with the consumption change simply because debt is often used to finance consumption and (relatedly) because the debt variables are endogenous with respect to any deleveraging the household has done. For this reason I try splitting the sample according to whether the household resided in a housing boom state or not, because those states also tended to see the largest housing busts, such that leverage saw a sharper increase. I also try instrumenting 2009 levels of leverage with households' 2007 leverage and 2007-09 home price growth in their state.

Third, given the noisiness of household data, the small size of the PSID sample is likely to make the estimates imprecise, particularly in cases where I focus on just a subset of the sample. Using broad measures of leverage and debt burden would reduce the sample size considerably, because a number of households do not report all of the information needed to calculate total debt, total assets, or total debt-service obligations. Hence, I focus on mortgage-related measures of debt and assets, which are available for most households.

Finally, I follow a long tradition in the empirical literature on householdlevel consumption and finances by using a transformation that downweights large values; Carroll, Dynan, and Spencer Krane (2003) provide a formal justification for doing so by showing that the residuals from a linear regression using household data are far from normally distributed. Using $\log$ differences in equation 2 is not desirable, however, because it would require dropping households with negative wealth, a group highly relevant to the question at hand. Instead, I take the inverse hyperbolic sine of consumption, income, and wealth before differencing. For a variable $x_{i t}$, the inverse hyperbolic sine is defined as

$$
\log \left[x_{i t}+\left(x_{i t}^{2}+1\right)^{\frac{1}{2}}\right] .
$$

Except in the case of very small values, the transformed variable can be interpreted in the same way as a logarithmic variable (see Woolley 2011 and Pence 2006 for further discussion). The drawback to moving away 
from a linear specification, however, is that one cannot interpret the coefficients on the income and wealth changes as marginal propensities to consume. For this reason I also estimate some specifications that are more in the spirit of the calculation done for table 3, dividing the first difference of consumption, income, and wealth by average family income across the 2005, 2007, and 2009 waves of the PSID.

\section{III.C. Regression Results}

Given that mortgage leverage and mortgage debt-service obligations are likely to be correlated, I begin with regressions that include just one measure or the other. Table 4 reports estimates based on equation 2 featuring 2007 mortgage leverage as the debt variable. The dependent variable is the change in nonhousing consumption over the period 2007-09. In the baseline specification, the inverse hyperbolic sine transformation is applied to consumption, income, and wealth before taking changes, and the changes are multiplied by 100 so that they roughly correspond to percent changes. The table shows the estimated coefficients for the change in the unemployment rate in the household's state of residence, the changes in household income and wealth, and the leverage measure. Also included in the regression are a constant, the age of the household head, whether the head has a college degree, the level of household income, and the level of the state unemployment rate, but the coefficients are not reported.

In the baseline specification (column 4-1), the estimated coefficients on the change in income and the change in wealth have the expected positive sign and are highly statistically significant. Conditional on the other variables, the change in the state unemployment rate is not significant, nor is the level of state unemployment rate (not shown). One might have expected these variables to have a significant negative relationship with consumption given that Carroll and others (2012) concluded that heightened uncertainty about job loss has induced a sizable precautionary saving response that has been weighing on consumption. Most of the other reported specifications show similar results for the changes in income, wealth, and state unemployment, although I note a few exceptions below.

The estimated coefficient on mortgage leverage in the baseline specification is negative and statistically significant at about the 6 percent level, suggesting that even after controlling for wealth and other traditional determinants of consumption, higher leverage did indeed weigh on consumption over the $2007-09$ period. At face value, the point estimate, -6.1 , suggests that the effect could be material: if one interprets the difference in the inverse hyperbolic sine (multiplied by 100) as the percent change, the 


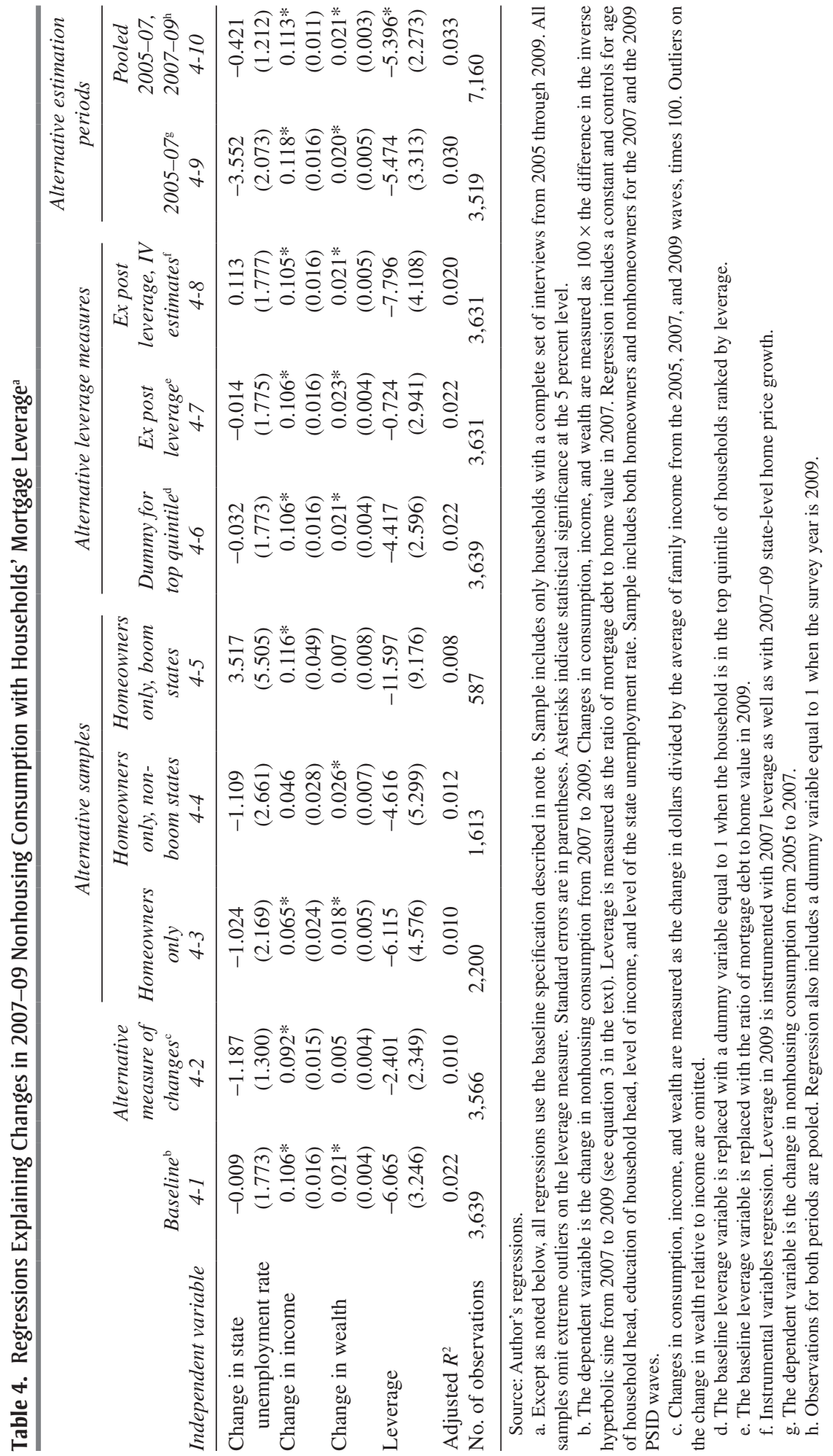


estimate implies that an increase in a household's mortgage loan-to-value ratio from 1.0 to 1.1 would have reduced its consumption growth by 0.6 percentage point over this 2-year period, or 0.3 percentage point per year.

In column 4-2, I replace the changes in consumption, income, and wealth with the first difference divided by average income over the 200509 period, multiplied by 100 . Unfortunately, the coefficient on the change in wealth is not precisely estimated, so the data are not helpful in uncovering the average marginal propensity to consume out of wealth. At 0.005 , the point estimate on the change in wealth looks small relative to the conventional belief that the marginal propensity to consume out of wealth is a few cents on the dollar (or even more), but the estimate is likely attenuated by measurement error in the PSID wealth data. ${ }^{17}$ Mortgage leverage again has a negative sign, but it is not statistically significant.

Columns 4-3 through 4-5 present estimates of the baseline specification for different subgroups of the PSID sample. Starting with the homeowner sample, which is about 40 percent smaller than the full sample, the estimated coefficient on mortgage leverage is similar to that in the baseline specification. However, it is statistically significant only at the 18 percent level because the standard error is much larger, which would be expected given the smaller sample size. Likewise, the standard errors are yet larger when the homeowner sample is split by whether the household resided in a state in the top quartile of house price appreciation between 2000 and 2006. Although not statistically significant, the estimates in these two columns suggest that leverage weighed much more on consumption in housing boom states than in other states. ${ }^{18}$ This pattern may reflect the fact that ex ante leverage understates any leverage-induced distress by more in the boom states, since the subsequent home price depreciation was larger in those states. I return to this issue when discussing columns 4-7 and 4-8.

I next vary the measure of leverage. In column 4-6, I replace mortgage leverage with a dummy variable indicating whether a household is in the top quintile of households by mortgage leverage; the estimate on this dummy is negative and statistically significant at the 9 percent level. In column 4-7, I replace 2007 mortgage leverage with 2009 mortgage leverage. As discussed above, given that much of the home price bust occurred after

17. Using a median estimator instead of ordinary least squares reduces the standard error by about half but has little effect on the magnitude of the coefficient on the wealth term. Restricting the coefficient on the wealth term to equal 0.05 , a more conventional estimate of the marginal propensity to consume, has little effect on the other estimation results.

18. This pattern for boom states and non-boom states shows up consistently in many variants on the specification shown here. 
the 2007 wave of the PSID, the ex post measure should better capture the mortgage distress relevant to the 2007-09 change in consumption. However, the problem with the ex post measure is that, to the extent that credit was still flowing over this period, some households likely borrowed more over the period in order to increase their consumption. For these households one might expect a positive relationship between ex post leverage and consumption. It is perhaps not surprising, then, that the estimated coefficient on leverage in this specification falls (in an absolute sense) to around zero. In column 4-8, I attempt to circumvent the bias induced by the endogeneity of debt with respect to consumption by instrumenting 2009 leverage with 2007 leverage as well as state-level home price growth. In this specification the estimated coefficient is a bit higher than in the baseline, at -7.8 , and statistically significant at the 6 percent level.

Column 4-9 reports the results obtained when the regression is estimated for the 2005-07 change in nonhousing consumption. One interpretation of my results thus far is that leverage itself somehow damps consumption, but an alternative explanation for the negative coefficients on leverage for the 2007-09 period is that low-wealth households are more sensitive to changes in their wealth and that higher leverage is simply proxying for lower wealth. If this alternative explanation were correct, however, one would expect a positive coefficient on the leverage variable over the 200507 period, when wealth was rising. The data speak against this alternative, as the coefficient and the standard error on the leverage term are quite similar to those in the baseline case for the 2007-09 period. Most of the other coefficients in the two regressions are also similar, although the estimated coefficient on the change in the state unemployment rate is much larger and statistically significant at the 9 percent level for the 2005-07 regressions. Column 4-10 reports the results obtained when the data are pooled (with a dummy variable for observations from the 2009 wave added); the estimated coefficient on leverage is -5.4 and is statistically significant at the 2 percent level.

Table 5 presents regressions where the debt variable is the 2007 mortgage debt-service burden, defined as the ratio of annual mortgage debtservice obligations to pretax household income. All other features of the baseline specification are the same as before. The estimated coefficient on the debt-service burden in the baseline specification is -6.8 and is statistically significant at the 6 percent level; taken at face value, this estimate would imply that, on average and all else equal, for every additional 10 percent of a household's income going toward debt service, one would expect its $2007-09$ consumption growth to have been 0.7 percentage point lower. 


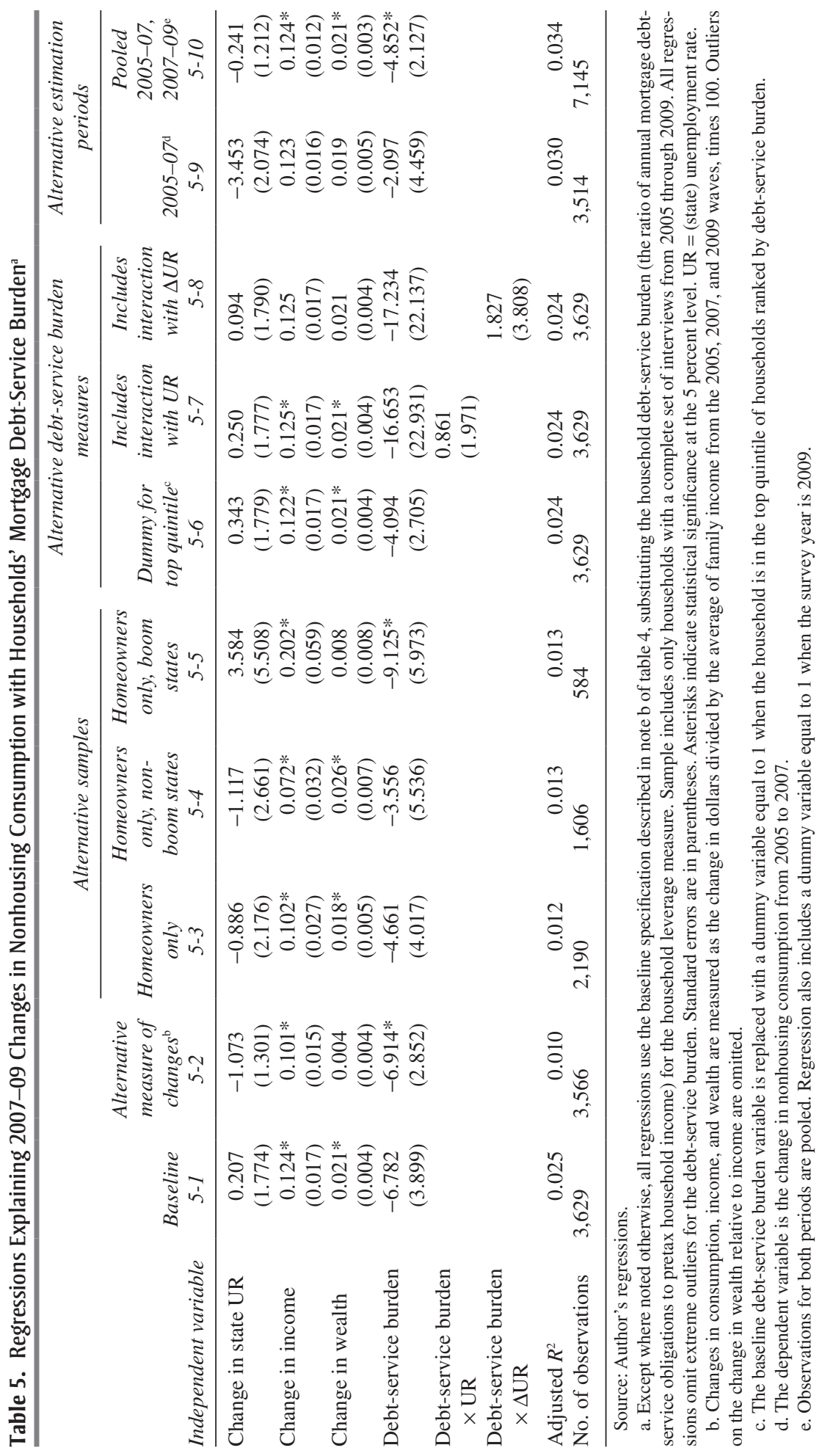


The negative coefficient shows up across the variants on the specification, with varying degrees of significance. Among the more notable results in the next few columns, one again sees a stronger effect in boom states than in non-boom states.

Columns 5-7 and 5-8 report results for specifications where an additional term, the interaction between the debt-service burden and the level of the state unemployment rate, is added, to explore the hypothesis that a higher debt-service burden is more likely to cause a retrenchment in consumption when the risk of job loss is high. (To make space for these variants, I omit the regressions that explore the results when ex post measures of debt are added; these specifications are less interesting in this case because one would not expect the same sort of dramatic change in debt service as for leverage over the 2007-09 period.) Although one might expect negative coefficients on the interaction terms under the hypothesis above, the coefficients are positive, but insignificant. Columns 5-9 and 5-10 report the estimates for the 2005-07 period and for the pooled sample, respectively. As in table 4, the negative effect of high indebtedness appears to prevail for the earlier period, although it is somewhat weaker.

Finally, table 6 reports the results obtained when both 2007 mortgage leverage and the 2007 mortgage debt service burden are included in the regression. This specification might be informative as to which debt variable is actually driving the relationship, which, in turn, could shed light on the underpinning of the relationship and may have policy implications. As one might expect given the correlation between the two variables, the coefficients are not very precisely estimated. Moreover, the coefficients on the variables are largely similar to those in tables 4 and 5. However, the coefficient on the debt-service burden is close to zero when the equation is estimated for the 2005-07 period, suggesting that, at least during the boom, debt-service obligations did not crowd out consumption after one controls for leverage. Such a pattern could be explained by the ease with which most homeowners were able to refinance and extract equity during the boom should they have run into cash-flow problems. ${ }^{19}$

On the whole, the regression analysis is limited by somewhat large standard errors. Still, the fairly consistent pattern of marginally significant negative coefficients on the debt variables supports the view that the debt

19. More work clearly needs to be done on this issue. If households had ready access to home equity during the boom, one might have expected the coefficient on current income to have been smaller in the 2005-07 regressions than in the 2007-09 regressions. I see no such pattern. 
Table 6. Regressions Explaining 2007-09 Changes in Nonhousing Consumption with Household Leverage and Debt-Service Burden ${ }^{\mathrm{a}}$

\begin{tabular}{|c|c|c|c|c|}
\hline \multirow[b]{2}{*}{ Independent variable } & \multirow[b]{2}{*}{$\begin{array}{c}\text { Baseline } \\
6-1\end{array}$} & \multirow[b]{2}{*}{$\begin{array}{c}\text { Ex post } \\
\text { leverage, IV }^{\text {estimates }} \\
\text { e-2 }\end{array}$} & \multicolumn{2}{|c|}{$\begin{array}{c}\text { Alternative estimation } \\
\text { periods }\end{array}$} \\
\hline & & & $\begin{array}{c}2005-07^{\mathrm{c}} \\
6-3\end{array}$ & $\begin{array}{c}\text { Pooled } \\
2005-07, \\
2007-09^{\mathrm{d}} \\
6-4\end{array}$ \\
\hline $\begin{array}{l}\text { Change in state } \\
\text { unemployment rate }\end{array}$ & $\begin{array}{c}0.191 \\
(1.776)\end{array}$ & $\begin{array}{c}0.268 \\
(1.778)\end{array}$ & $\begin{array}{l}-3.561 \\
(2.077)\end{array}$ & $\begin{array}{c}-0.250 \\
(1.213)\end{array}$ \\
\hline Change in income & $\begin{array}{l}0.122 * \\
(0.017)\end{array}$ & $\begin{array}{l}0.122 * \\
(0.017)\end{array}$ & $\begin{array}{l}0.121^{*} \\
(0.016)\end{array}$ & $\begin{array}{l}0.122 * \\
(0.012)\end{array}$ \\
\hline Change in wealth & $\begin{array}{c}0.020^{*} \\
(0.004)\end{array}$ & $\begin{array}{c}0.021^{*} \\
(0.005)\end{array}$ & $\begin{array}{c}0.019^{*} \\
(0.005)\end{array}$ & $\begin{array}{r}0.020^{*} \\
(0.003)\end{array}$ \\
\hline Leverage & $\begin{array}{l}-4.108 \\
(3.535)\end{array}$ & $\begin{array}{l}-5.234 \\
(4.433)\end{array}$ & $\begin{array}{l}-5.108 \\
(3.615)\end{array}$ & $\begin{array}{l}-4.192 \\
(2.430)\end{array}$ \\
\hline Debt-service burden & $\begin{array}{c}-4.849 \\
(4.240)\end{array}$ & $\begin{array}{c}-5.039 \\
(4.217)\end{array}$ & $\begin{array}{c}0.590 \\
(4.853)\end{array}$ & $\begin{array}{l}-3.658 \\
(2.237)\end{array}$ \\
\hline Adjusted $R^{2}$ & 0.025 & 0.025 & 0.031 & 0.034 \\
\hline No. of observations & 3,627 & 3,619 & 3,512 & 7,141 \\
\hline
\end{tabular}

Source: Author's regressions.

a. Except where noted otherwise, all regressions use the baseline specification described in note b of table 4, except that the household debt-service burden from table 5 is also included. Sample includes only households with a complete set of interviews from 2005 through 2009. Regressions drop extreme outliers for leverage and the debt-service burden. Standard errors are in parentheses. Asterisks indicate statistical significance at the 5 percent level.

b. Instrumental variables regression; leverage is defined as the ratio of mortgage debt to home value in 2009 .

c. The dependent variable is the change in nonhousing consumption from 2005 to 2007.

d. Observations for both periods are pooled. Regression also includes a dummy variable equal to 1 when the survey year is 2009 .

overhang produced by the drop in home prices represents an additional headwind for consumption-above and beyond the direct wealth effects associated with lower home prices.

\section{More-Recent Evidence about the Highly Indebted}

As discussed earlier, preliminary partial data on household balance sheets and mortgage payment problems from the 2011 wave of the PSID have recently been released. The data represent just a small subset of the variables that will ultimately be available, and they are subject to revision. Still, the information is highly relevant and timely (particularly by the standards of household surveys) and thus worth exploring. 


\section{IV.A. Mortgage Payment Problems}

Figure 5 shows changes in various variables related to mortgage payment problems between 2009 and 2011, again comparing homeowners who were in the top quintile of mortgage leverage as of 2007 with others and dividing homeowners by whether they resided in a housing boom state or not. ${ }^{20}$ Broadly speaking, it remained the case in 2011 that homeowners with the highest ratios of mortgage debt to home value in 2007 were more likely to have or expect problems making their mortgage payments than other homeowners. Distress also remained more pronounced in the former boom states (those in the top quartile of states in terms of home price appreciation between 2000 and 2006) than elsewhere.

The top left-hand panel of the figure shows a small decline between 2009 and 2011 in the fraction of highly leveraged households who were behind on their mortgage payments. This pattern is consistent with the decline in mortgage delinquency rates seen in the aggregate data. The number of highly leveraged homeowners in housing boom states who were in foreclosure rose between 2009 and 2011, as shown in the top right-hand panel. The nationwide foreclosure crisis does not show up very clearly, but the figure includes only households that were in the process of foreclosure, not those for whom a foreclosure had been completed. ${ }^{21}$

A smaller share of 2007 homeowners reported being somewhat likely to fall behind on their mortgage payments in 2011 than in 2009 (middle left-hand panel), but a larger share reported being very likely to fall behind (middle right-hand panel). Thus, the data do not show a clear pattern of improvement in terms of expected mortgage payment problems. Summing across the two panels, one observes that the share of highly leveraged homeowners in boom states that reported being either somewhat or very likely to experience mortgage payment problems remained quite elevated, declining by just 3 percentage points, from 28 percent to 25 percent. One might have expected a larger decline given that a considerable share of this group underwent major changes in their housing situation between 2009 and 2011 (presumably, in many cases, relieving mortgage-related pressures they had

20. To be consistent, I also impose the other restrictions from table 2 and table 3 , namely, including just those homeowners who had a complete set of interviews from 2005 through 2009 and who were not retired over this period.

21. Even so, at fewer than 2 percent of the mortgage holders in the 2011 sample as a whole, the number of households with mortgages in foreclosure seems relatively small. Although the PSID has very high rates of sample retention from wave to wave, it may also be the case that households in foreclosure are more difficult to find and interview. 
Figure 5. Mortgage Distress in 2009 and 2011 among PSID Households Who Owned Homes in $2007^{a}$

Behind on mortgage payments

Percent of 2007 homeowners

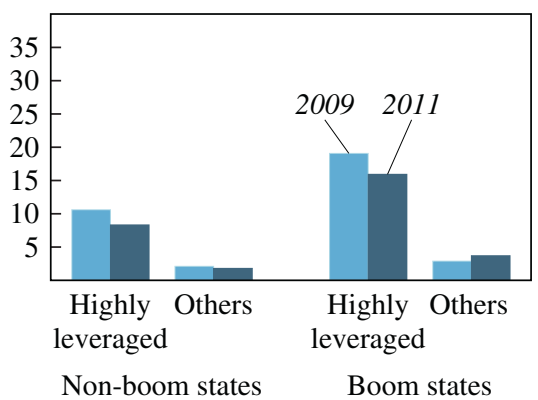

"Somewhat likely" to fall behind on payments

Percent of 2007 homeowners

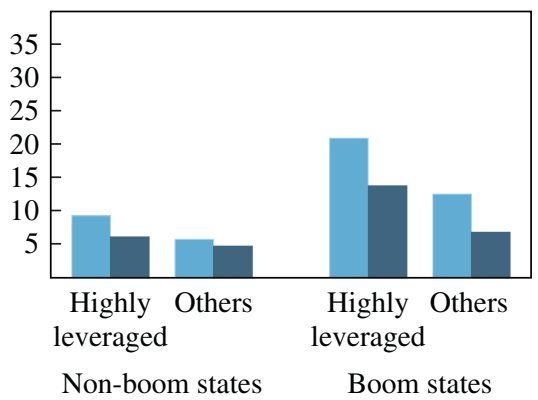

Moved since 2007

Percent of 2007 homeowners

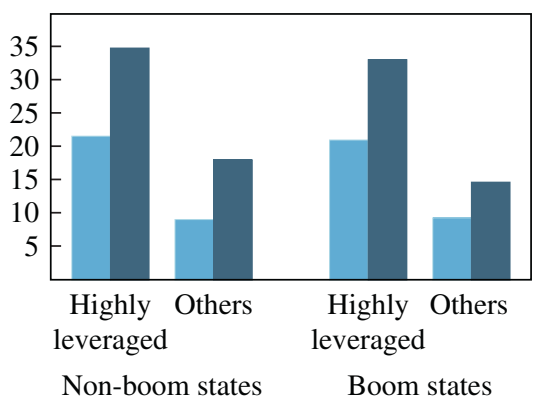

Source: Author's calculations from PSID data. a. Subsamples are as defined in table 2 .

\section{Foreclosure started}

Percent of 2007 homeowners

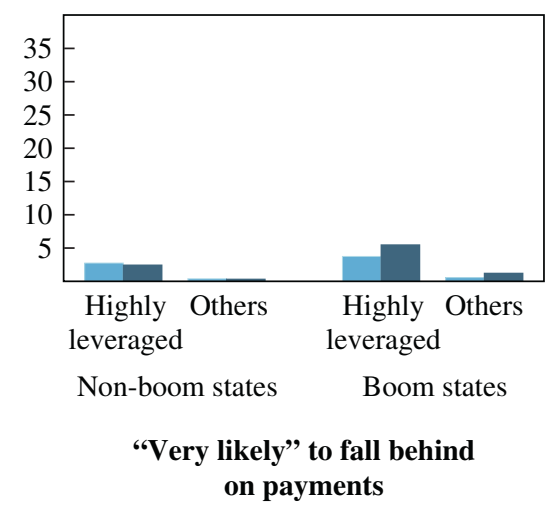

Percent of 2007 homeowners

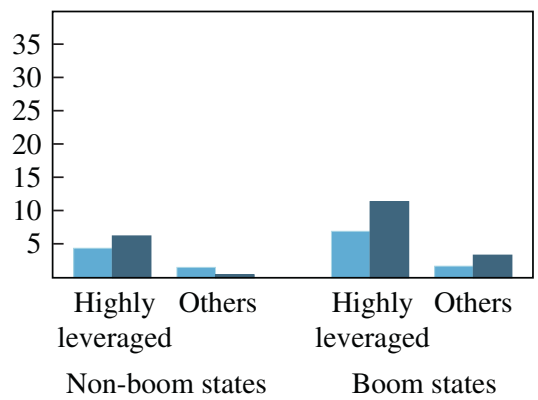

No longer own a home

Percent of 2007 homeowners

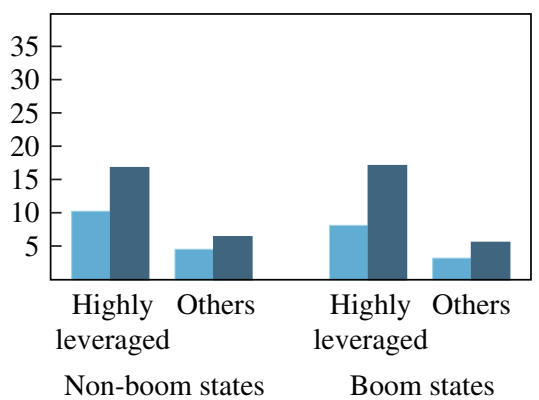


faced): about a third of this group had moved since 2007 (up from 21 percent in 2009), and 17 percent were no longer homeowners at all (up from 8 percent in 2009).

In sum, the preliminary 2011 PSID data on mortgage distress do not paint a particularly encouraging picture. Although homeowners were better off by some measures, they continued to anticipate a fair degree of difficulty servicing their loans-and that result is especially strong among households who had high ratios of mortgage debt to home value in 2007. Perhaps, however, the finding is not surprising given that macroeconomic conditions remained very weak.

\section{IV.B. How Much More Deleveraging Is to Come?}

One way to assess how much deleveraging is still to come is to examine where a household's leverage ratio stands relative to where that household might like it to be. Households likely choose target levels of leverage based on a variety of factors, including what levels of leverage preclude access to low-cost credit, what levels imply they would not be able to pay off their mortgages if they were to sell their homes, and what levels simply seem excessive. Given this, it is difficult to estimate a target level of leverage for any given household with confidence. However, one reasonable benchmark for such a target might be the level of mortgage leverage the household had in the precrisis period.

Table 7 presents results of such an exercise for households in the 2009 and 2011 waves of the PSID. Each panel from left to right assumes a different target for household leverage, specified as the actual mortgage loanto-value ratio as of some previous year $(2003,2005$, or 2007), and the rows report the shares of households in 2009 and 2011 whose actual ratios exceeded that target by 10 percent or less, 20 percent or less, and so on. In all panels, households who became homeowners after the target year are assumed to be trying to reduce their mortgage leverage ratio to 90 percent. The results in the different panels are fairly similar, suggesting that the analysis is not very sensitive to which year's ratios are assumed to be the target. This is perhaps not surprising given that aggregate mortgage leverage did not move much during the credit boom, implying that, on average, mortgage debt was about keeping pace with home price growth.

The results of the exercise suggest that, as of 2011, between a fifth and a quarter of households were above their assumed mortgage leverage targets. A small but material share-between 4 and 5 percent-were above their targets by 50 percent or more. (Note that the shares of mortgage borrowers above target would be much higher, given that the sample here 
Table 7. Households' Success in Meeting Hypothetical Mortgage Leverage Targets, 2009 and $2011^{\mathrm{a}}$

\begin{tabular}{|c|c|c|c|c|c|c|}
\hline \multirow{4}{*}{$\begin{array}{l}\text { Amount by which actual } \\
\text { mortgage LTV ratio is above } \\
\text { the indicated target }\end{array}$} & \multicolumn{6}{|c|}{ Target LTV ratio and PSID year } \\
\hline & \multicolumn{2}{|c|}{$\begin{array}{c}\text { Target }=\text { actual } \\
2003\end{array}$} & \multicolumn{2}{|c|}{$\begin{array}{c}\text { Target }=\text { actual } \\
2005\end{array}$} & \multicolumn{2}{|c|}{$\begin{array}{c}\text { Target }=\text { actual } \\
2007\end{array}$} \\
\hline & 2009 & 2011 & 2009 & 2011 & 2009 & 2011 \\
\hline & PSID & PSID & PSID & $P S I D$ & PSID & PSID \\
\hline & \multicolumn{6}{|c|}{$\begin{array}{c}\text { Percent of households above target ratio } \\
\text { by indicated amount }{ }^{\mathrm{b}}\end{array}$} \\
\hline More than 0 percentage points & 19.4 & 21.7 & 21.9 & 23.7 & 24.4 & 25.3 \\
\hline More than 10 percentage points & 13.4 & 15.9 & 13.8 & 16.9 & 14.5 & 17.5 \\
\hline More than 20 percentage points & 9.5 & 11.1 & 9.6 & 11.6 & 8.8 & 12.4 \\
\hline More than 30 percentage points & 6.4 & 8.6 & 6.9 & 8.9 & 5.9 & 8.7 \\
\hline More than 40 percentage points & 4.8 & 5.9 & 5.0 & 6.5 & 4.3 & 6.2 \\
\hline More than 50 percentage points & 3.2 & 4.4 & 3.8 & 4.8 & 3.3 & 4.8 \\
\hline
\end{tabular}

Source: Author's calculations using PSID data.

a. Results are for all households, including households without mortgages, that had interviews in the year in which the actual LTV ratio was captured and the year on which the target was based. In all panels, for households that purchased a home after the target year, the target ratio is assumed to be 90 percent.

b. Percentages are calculated on a weighted basis.

also includes both nonhomeowners and homeowners without mortgages.) Another striking result is that, on the whole, households appeared to be in somewhat worse shape in terms of their mortgage leverage ratios in 2011 than in 2009. It is known that some households reduced leverage dramatically by defaulting on their mortgages, but others likely sank further underwater because their home values continued to fall..$^{22}$

Meeting these targets would be no easy task for some homeowners. Table 8 offers evidence on what it would take for PSID households to bring their mortgage leverage ratios down to an assumed target if they were to do so solely by paying off their mortgage debt. Here the assumed target for each household is its 2005 mortgage leverage ratio unless that household became a homeowner since 2005, in which case the target ratio is assumed to be 90 percent. For each household I calculate how many months or years of its pretax income would need to be diverted toward repayment in order

22. On an annual average basis, the CoreLogic index of national home prices fell by about 5 percent between 2009 and 2011. In addition, as discussed earlier, there is some evidence that the PSID homeowners' assessments of their home values lag the actual data, implying that their 2009 leverage ratios may have been understated because households had not yet fully internalized the earlier plunge in home prices. 
Table 8. Deleveraging Needed to Bring Mortgage Leverage Back to Precrisis Norms ${ }^{\mathrm{a}}$

\begin{tabular}{lc}
$\begin{array}{c}\text { Debt reduction needed to bring } \\
\text { mortgage leverage to target }\end{array}$ & $\begin{array}{c}\text { Percent of PSID } \\
\text { households }\end{array}$ \\
\hline No reduction needed & 76.3 \\
0-1 months of income & 2.7 \\
2-3 months of income & 4.7 \\
3-6 months of income & 4.6 \\
6-12 months of income & 4.8 \\
1-2 years of income & 4.0 \\
2-3 years of income & 1.6 \\
3+ years of income & 1.4
\end{tabular}

Source: Author's calculations using PSID data.

a. Results are for all households in both the 2009 and the 2011 waves of the PSID. Income is pretax income captured as of the 2009 wave and therefore corresponds to calendar 2008. Percentages are calculated on a weighted basis.

b. Assumed target is the homeowner's actual mortgage leverage ratio in 2005, except for households who became homeowners after 2005, for whom the assumed target is 90 percent.

to accomplish the needed reduction in debt. ${ }^{23}$ The table shows the number of households falling in specific ranges of the amount of pretax income that would need to be diverted. Note, however, that even households needing just a few months' worth of debt reduction might have to make a considerable change to their saving and consumption behavior to accomplish that reduction over a limited time frame: diverting just an additional month's worth of pretax income to paying down debt over the course of a year could be a big deal for a household whose income and finances have already been stretched thin by weak macroeconomic conditions.

Table 8 shows that a little more than three-quarters of PSID households (again including both homeowners and nonhomeowners) already had mortgage leverage ratios below their assumed target in 2011. About another 7 percent of the sample could get there with a fairly modest reduction in debt-equivalent to 3 months or less of pretax income. But 7 percent needed to reduce their debt by more than a year's worth of pretax income, and $1 \frac{1}{2}$ percent need to reduce debt by more than 3 years' worth. This exercise shows that if this deleveraging were accomplished by saving alone, it

23. Quantifying the reduction in terms of after-tax income might be more meaningful, but the PSID does not provide information about households' after-tax income. I use the households' most recently reported income (the figure in the 2009 wave, which corresponds to calendar 2008). The results do not change much if I use average household income over several recent waves of the PSID instead of a single year's reading. 
could mean a fairly drastic cut in consumption for many years for a small share of households.

Getting back to 2005 values of leverage might seem a high bar for a lot of households. However, anecdotal evidence is consistent with the view that many households would like to reduce their debt, and with the view that many feel they have made little, if any, progress. For example, in one survey of roughly 1,000 adults between the ages of 25 and 65,45 percent of respondents said that they felt their debt was too high relative to their income in March 2012 (Absolute Strategy Research 2012). The share was up a bit from the share a year earlier (45 percent). When asked whether the financial crisis had changed their attitudes toward debt, 35 percent of households responded, "Yes: I now plan to reduce my total debt level over the next 12 months."

Of course, households can reduce their leverage in other ways. They can sell their homes and use the proceeds to pay down mortgage debt, or they can default on their mortgage obligations. They can also achieve reduced leverage if the value of their home rises, although many households may be reluctant to count on such an outcome given the experience of the last decade.

\section{Discussion}

The plunge in home prices between 2007 and 2009 left enormous scars on households' balance sheets. Many people who had taken advantage of rising home prices and easy credit conditions during the early to mid-2000s to borrow large amounts were left with considerable debt overhangs in the form of elevated mortgage debt-to-asset ratios. The estimates in this paper provide evidence that the spending of such households has been especially weak-more so than would be expected based on other factors affecting them, including the decline in wealth they experienced. One implication is that the traditional approach to analyzing and forecasting aggregate consumer spending - which does not take levels of leverage into accountmay be misleading policy analysts who rely on it.

That said, it is difficult to use the estimates in this paper to quantify the degree to which the household debt overhang is holding back consumption. The point estimates from my regressions suggest that an increase in a household's mortgage leverage ratio of 10 percent is associated with a reduction in annual consumption growth of a few tenths of a percentage point. With the roughly half of Americans who have mortgages experiencing considerable jumps in leverage as a result of the roughly one-third 
decline in home prices nationwide, one might conclude that excessive leverage is having a noticeable (albeit modest) damping effect on aggregate consumption growth. However, my estimates have relatively large standard errors, suggesting that the confidence interval around such an assessment is large. Moreover, before drawing firm conclusions, one would want to explore whether there are important nonlinearities in the relationship (such as whether the leverage ratio only matters when it is above a certain level) and whether the results hold up in more recent data (which, for the PSID, are not yet available).

My results also suggest that, on the whole, households have made very limited progress in recent years at reducing excess mortgage leverage. Although some households are known to have dramatically reduced their leverage by defaulting, my data show that the shares of households with ratios exceeding various possible targets actually increased between 2009 and 2011. Important financial strains persist, as evidenced by the fact that there was essentially no reduction between 2009 and 2011 in the share of homeowners reporting that they were somewhat or very likely to have problems making their mortgage payments over the coming year. Further, my results suggest that it may take many years for some households to reduce their leverage to precrisis norms. The effects of deleveraging on the economy could thus persist for some time to come.

More research is needed to discern the mechanism through which the debt overhang is restraining households' spending. Highly indebted households may be deliberately holding back their spending in order to return their leverage to what they perceive as more manageable levels. Alternatively, they may be unable to spend more because they are especially constrained from borrowing in the current environment of tight credit. Or their leverage may be impeding their ability to lower their monthly mortgage obligations by refinancing into loans with lower interest rates. In the last case, one would expect more of a pickup in consumption as credit conditions ease.

ACKNOWLEDGMENTS I thank John Soroushian for research assistance and Chris Carroll, Doug Elmendorf, Don Kohn, Atif Mian, Karen Pence, and the editors for comments and discussion. 


\section{References}

Absolute Strategy Research. 2012. "ASR's U.S. Survey of Household Finances." London (March 19). www.politico.com/pdf/PPM192_asr_consumer_finance_ survey-full_report.pdf.

Bernanke, Ben S. 2012. "Housing Markets in Transition." Speech at the 2012 National Association of Homebuilders International Builders' Show, Orlando, Fla., February 10. www.federalreserve.gov/newsevents/speech/ber nanke20110210a.htm.

Bhutta, Neil. 2012. "Mortgage Debt and Household Deleveraging: Accounting for the Decline in Mortgage Debt Using Consumer Credit Record Data." Finance and Economics Discussion Series no. 2012-14. Washington: Board of Governors of the Federal Reserve (March). www.federalreserve.gov/pubs/ feds/2012/201214/201214pap.pdf.

Bhutta, Neil, Jane Dokko, and Hui Shan. 2010. "The Depth of Negative Equity and Mortgage Default Decisions." Finance and Economics Discussion Series no. 2010-35 (May). Washington: Board of Governors of the Federal Reserve. www.federalreserve.gov/pubs/feds/2010/201035/201035pap.pdf.

Bosworth, Barry P., and Rosanna Smart. 2009. "Evaluating Micro-Survey Estimates of Wealth and Saving." Brookings (February). www.brookings.edu/ /media/ Files/rc/papers/2009/01_micro_survey_bosworth/01_micro_survey_bosworth. pdf.

Bricker, Jesse, Brian Bucks, Arthur B. Kennickell, Traci L. Mach, and Kevin B. Moore. 2011. "Surveying the Aftermath of the Storm." Finance and Economics Discussion Series no. 2011-17. Washington: Board of Governors of the Federal Reserve (March). www.federalreserve.gov/pubs/feds/2011/201117/201117pap. pdf.

Brown, Meta, Andrew Haughwout, Donghoon Lee, and Wilbert van der Klaauw. 2011. "Have Consumers Been Deleveraging?" Liberty Street Economics Blog. Federal Reserve Bank of New York (March). libertystreeteconomics.newyork fed.org/2011/03/have-consumers-become-more-frugal.html.

Carroll, Christopher D., Karen E. Dynan, and Spencer D. Krane. 2003. "Unemployment Risk and Precautionary Wealth: Evidence from Households' Balance Sheets." Review of Economics and Statistics 85 (August): 586-604.

Carroll, Christopher, Jiri Slacalek, and Martin Sommer. 2012. "Dissecting Saving Dynamics: Measuring Credit, Wealth and Precautionary Effects." Johns Hopkins University (January). www.econ2.jhu.edu/people/ccarroll/papers/cssUS Saving.pdf.

Davis, Morris A., and Michael G. Palumbo. 2001. "A Primer on the Economics and Time Series Econometrics of Wealth Effects." Finance and Economics Discussion Series no. 2001-09. Washington: Board of Governors of the Federal Reserve (January). www.federalreserve.gov/pubs/feds/2001/200109/200109abs.html.

Disney, Richard, Sarah Bridges, and John Gathergood. 2010. "House Price Shocks and Household Indebtedness in the United Kingdom." Economica 77: 472-96. 
Dynan, Karen. 2009. "Changing Household Financial Opportunities and Economic Security." Journal of Economic Perspectives 23 (Fall): 49-68.

2011. "Household Deleveraging in 2011: Progress, but More to Come." Brookings. www.brookings.edu/opinions/2011/1219_household_deleveraging_ dynan.aspx.

. 2012. "What's Been Weighing on Consumption? An Overview of the Recent Experiences of Different Types of Households." Prepared for the Federal Reserve Board Academic Consultants Meeting on "Heterogeneity and Aggregate Consumption." Brookings. www.brookings.edu/research/papers/2012/05/ household-heterogeneity-dynan.

Foote, Christopher, Kristopher S. Gerardi, Loren Goette, and Paul Willen. 2010. "Reducing Foreclosures: No Easy Answers." NBER Macroeconomics Annual 24: 89-238.

Gagnon, Joseph E. 2011. "The Last Bullet." RealTime Economic Issues Watch Blog. Washington: Peterson Institute for International Economics (October 24). www.piie.com/blogs/?p=2456.

Goodman, Laurie S. 2011. "New Ideas to Address the Glut of Foreclosed Properties." Testimony before the Subcommittee on Housing, Transportation and Community Development of the Senate Committee on Banking, Housing and Urban Affairs (September 20).

Greenspan, Alan, and James Kennedy. 2007. "Sources and Uses of Equity Extracted from Homes." Oxford Review of Economic Policy 24, no. 1: 120-44.

Howard, Greg, Robert Martin, and Beth Anne Wilson. 2011. “Are Recoveries from Banking and Financial Crises Really So Different?” International Finance Discussion Paper no. 1037. Washington: Board of Governors of the Federal Reserve System (November). www.federalreserve.gov/pubs/ifdp/2011/1037/ ifdp1037.pdf.

Iacoviello, Matteo. 2005. "House Prices, Borrowing Constraints, and Monetary Policy in the Business Cycle." American Economic Review 95 (June): 739-64.

Johnson, Kathleen W., and Geng Li. 2007. "Do High Debt Payments Hinder Household Consumption Smoothing?" Finance and Economics Discussion Series no. 2007-52. Washington: Board of Governors of the Federal Reserve www.federalreserve.gov/pubs/feds/2007/200752/200752abs.html.

Keys, Benjamin, Tanmoy Mukherjee, Amit Seru, and Vikrant Vig. 2010. "Did Securitization Lead to Lax Screening? Evidence from Subprime Loans." Quarterly Journal of Economics 125, no. 1: 307-62.

Li, Geng, Robert F. Schoeni, Sheldon Danziger, and Kerwin Kofi Charles. 2010. "New Expenditure Data in the PSID: Comparisons with the CE." Monthly Labor Review (February): 29-39.

Ludvigson, Sydney. 1999. "Consumption and Credit: A Model of Time-Varying Liquidity Constraints." Review of Economics and Statistics 81 (August): 434-47.

Mayer, Christopher, Karen Pence, and Shane M. Sherlund. 2009. "The Rise in Mortgage Defaults.” Journal of Economic Perspectives 23, no. 1: 27-50. 
Mian, Atif R., and Amir Sufi. 2011. "What Explains High Unemployment? The Aggregate Demand Channel Household Balance Sheets, Consumption, and the Economic Slump." University of California, Berkeley, and University of Chicago (November). faculty.chicagobooth.edu/amir.sufi/MianSufi_WhatExplains Unemployment_Nov2011.pdf.

Mian, Atif R., Kamalesh Rao, and Amir Sufi. 2011. "Household Balance Sheets, Consumption, and the Economic Slump." University of California, Berkeley, and University of Chicago (November). ssrn.com/abstract=1961211 or dx.doi. org/10.2139/ssrn.1961211.

Mishkin, Frederic S. 1977. "What Depressed the Consumer? The Household Balance Sheet and the 1973-75 Recession." BPEA, no. 1: 123-64.

Pence, Karen M. 2006. "The Role of Wealth Transformations: An Application to Estimating the Effect of Tax Incentives on Saving." Contributions to Economic Analysis \& Policy 5, no. 1: Article 20.

Reinhart, Carmen M., and Kenneth S. Rogoff. 2009. "The Aftermath of Financial Crises." American Economic Review 99 (May): 466-72.

Saez, Emmanuel. 2012. "Striking It Richer: The Evolution of Top Incomes in the United States (Updated with 2009 and 2010 Estimates)." University of California, Berkeley (March 2) elsa.berkeley.edu/ saez/saez-UStopincomes-2010.pdf.

Stafford, Frank P., Elena Gouskova, and Bing Chen. 2012. "Mortgage Contract Decisions and Mortgage Distress: Family and Financial Life Cycle Factors." University of Michigan (March).

Woodward, Susan E., and Robert E. Hall. 2012. "The Quantitative Importance of Household Deleveraging in the Great Recession." Stanford University. (March 8).

Woolley, France. 2011. "A Rant on Inverse Hyperbolic Sine Transformations." Worthwhile Canadian Initiative Blog (July 5). worthwhile.typepad.com/worth while_canadian_initi/2011/07/a-rant-on-inverse-hyperbolic-sine-transformations. html. 


\section{Comments and Discussion}

\section{COMMENT BY}

ATIF MIAN This paper by Karen Dynan analyzes data from the Panel Study of Income Dynamics (PSID) to test to what extent a debt overhang among indebted households is responsible for the reduction in aggregate demand during the Great Recession and the lackluster recovery. The paper exploits cross-sectional variation in exposure to the credit and housing boom of the 2000s and documents the following main results: first, homeowners in areas where many households are highly indebted (which are also areas of high home price growth) have experienced sharper declines in spending than other households; second, this decline in spending cannot be explained by a pure wealth effect and thus partly represents a pure debt overhang or deleveraging effect; third, highly indebted households are finding it difficult to reduce their debt, and this difficulty is leading to a sluggish recovery.

The paper addresses a very important question for anyone interested in understanding the current economic downturn. My bottom line is that I agree with the paper's central message: household debt overhang is holding back consumption. Dynan's main result reinforces one of the findings in my own recent work with Kamalesh Rao and Amir Sufi (Mian, Rao, and Sufi 2012). I find it reassuring that the two papers arrive at similar conclusions despite using different data sources to measure consumption and the debt overhang. In what follows I will discuss the data and methodology used in Dynan's work, and end with a discussion of what we learn from it for future monetary and fiscal policy.

HOUSEHOLD DEBT OVERHANG AND CONSUMPTION Macroeconomists have long emphasized that in a leveraged financial system, financial shocks (such as shocks to asset prices) have important distributional consequences that in turn affect real outcomes. However, the focus of such discussions has largely been on the investment channel. For example, the bank lending 
channel literature argues that negative financial shocks disproportionately hurt the balance sheets of leveraged financial intermediaries. This reduction in their net worth forces them to cut back on lending because of insufficient equity capital. The standard monetary and fiscal policy response to business cycle downturns is largely colored by this view of the world: during a downturn, banks need to be recapitalized and flushed with liquidity in order to avoid a sharp cut in aggregate investment.

An abundance of historical evidence leaves no doubt that the investmentdriven balance sheet channel is important for understanding economic downturns. However, the most recent recession has reminded us of something learned from the Great Depression (most notably from Irving Fisher's work), namely, that another powerful mechanism at play could be the aggregate demand or consumption channel. In an environment where a large fraction of households have borrowed heavily (as in both 1929 and 2007), a drop in home prices has serious distributional consequences. In particular, highly leveraged borrowers may suddenly find themselves "under water," with their mortgage debt exceeding the value of their homes, forcing them to cut back on consumption in an effort to regain financial health. If monetary policy, through reduced interest rates, is unable to convince other, less leveraged or unleveraged households to increase their consumption significantly at the same time, the result could be a reduction in aggregate consumption.

Is there evidence from the 2007-09 recession that such an exposure to debt caused households to reduce their consumption? Karen Dynan evaluates this question using the PSID data between 2007 and 2009 and answers in the affirmative.

Dynan's empirical methodology is based on the observation that under the consumption-driven view of the Great Recession, households with higher leverage ex ante should cut back more on their consumption than others. The most basic empirical test uses the following cross-sectional regression:

$$
\Delta C_{i}=\alpha+\beta_{w} \Delta W_{i}+\beta_{\mathrm{lev}}\left(\frac{D}{A}\right)_{i, 2007}+\gamma X_{i}+\varepsilon_{i},
$$

where changes are taken over the 2007-09 period. Here $\Delta W_{i}$ captures the change in wealth for a household, driven by home price declines, and $(D / A)_{i, 2007}$ captures the initial leverage. One would expect more highly leveraged households to cut back more on their consumption, so that $\beta_{\text {lev }}<0$.

The paper estimates equation 1 above using PSID data and finds $\beta_{w}$ to be positive (consistent with a wealth effect) and $\beta_{\text {lev }}$ to be negative (consis- 
Figure 1. Home Prices in High- and Low-Leverage Counties, 2005-10

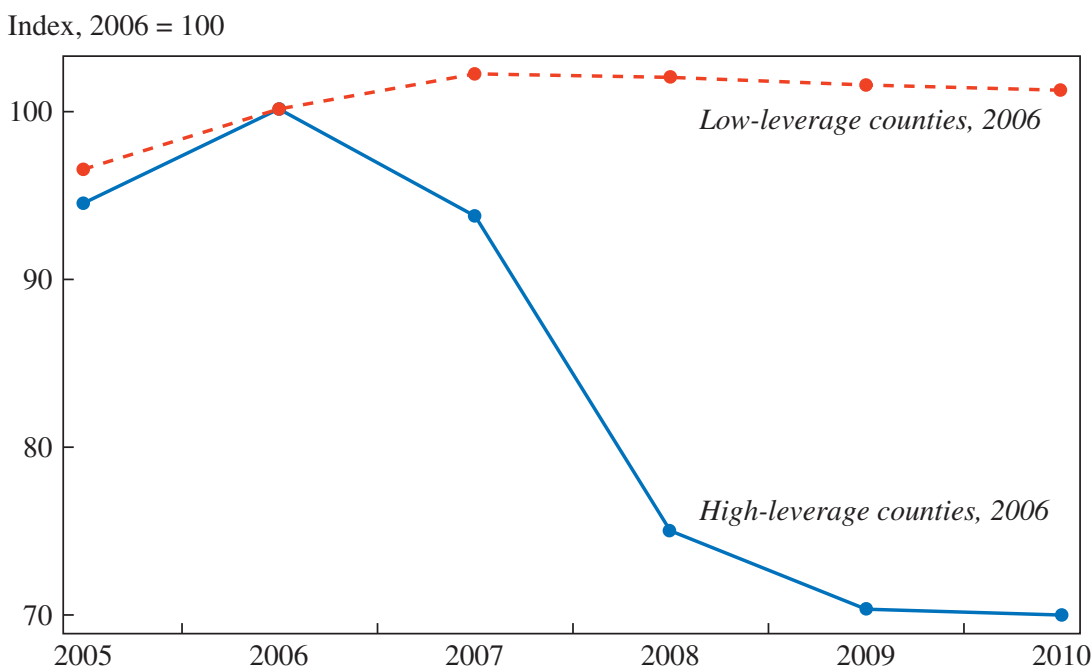

Source: Author's calculations using Federal Housing Finance Authority data.

a. High-leverage and low-leverage counties are defined as the top and the bottom decile, respectively, of the distribution ranked by the predicted value of the 2006 debt-to-income ratio, as estimated from an instrumental variables regression where housing supply elasticity is used as an instrument. Deciles are weighted by population.

tent with a debt-overhang effect). My main comment on the methodology is that extra care needs to be taken in estimating and interpreting these coefficients. In particular, before estimating equation 1 , two questions need to be addressed:

-Where is the variation in leverage coming from? That is, are highly and less highly leveraged households otherwise identical?

- Initial leverage and the change in wealth over 2007-09 might be highly correlated. Can one legitimately identify $\beta_{w}$ and $\beta_{\text {lev }}$ separately?

Regarding the first question, an unconditional comparison of highly leveraged and less highly leveraged households might be problematic if high household leverage is naturally a more cyclical phenomenon. For example, highly leveraged households may be more likely to be subprime borrowers and more likely to be laid off on the margin. Thus, ideally one would need an instrument for leverage.

The second question is even more problematic given the very strong correlation between leverage and wealth (home price) shocks in the data. My figure 1, borrowed from Mian and others (2012), compares home price growth in high-leverage U.S. counties (defined as the top 10 percent of 
counties in terms of the ratio of household debt to income as of 2006) with that in low-leverage counties (the bottom 10 percent of the same distribution). One can see that the high-leverage group suffered a sharp average home price decline during the sample period, whereas the low-leverage group experienced almost no decline. Thus, controlling for the change in wealth as in equation 1 is not straightforward.

The high correlation between leverage and home price growth suggests that a common underlying factor is responsible for both. Indeed, Mian and Sufi (2011a) show that leverage by 2007 had accumulated to a large extent from high rates of borrowing against rising home values. Thus, the rapid home price growth caused the higher leverage.

Why did home prices grow faster in certain areas than others? Mian and Sufi (2011a) show that a dominant factor in explaining cross-sectional variation in home price growth is the elasticity of housing supply: areas where it is more difficult to build new housing, because of geographical barriers such as hills or bodies of water, experience faster home price growth. Thus, a common underlying factor-housing supply elasticityserves as an instrument for both the level of leverage at the height of the housing bubble and the subsequent collapse in house prices.

The discussion thus far suggests that one can use housing supply elasticity as an instrument for leverage in equation 1. However, the same reasoning also implies that one cannot estimate leverage separately from the wealth shock. Although leverage and wealth shocks may not be perfectly collinear in the data, it is not clear how to interpret the variation in leverage conditional on wealth shocks. For example, what kinds of households have the same level of wealth shocks but differ significantly in their leverage? The question of endogenous leverage becomes even more important when one forces the coefficient to be estimated off of conditional variation.

Given these considerations, I would not worry about "controlling" for changes in wealth, but would instead estimate the direct effect of leverage on consumption after instrumenting for leverage with the housing supply instrument. It should be clear that the resulting coefficient includes both a wealth effect and a debt overhang effect. Can one then do anything to separate these two effects? I address this question next.

SEPARATING THE WEALTH EFFECT FROM THE DEBT OVERHANG EFFECT Given the strong correlation and joint determinacy of wealth shocks and leverage, one needs to resort to theory to get some guidance on how likely it is that the effect of leverage on consumption is driven by a pure wealth effect. I would suggest estimating the instrumented equation 1 without the wealth shock and then evaluating the magnitude of the resulting 
Figure 2. Consumption by Category in High- and Low-Leverage Counties, 2005-10a

Automobiles

Index, $2006=100$

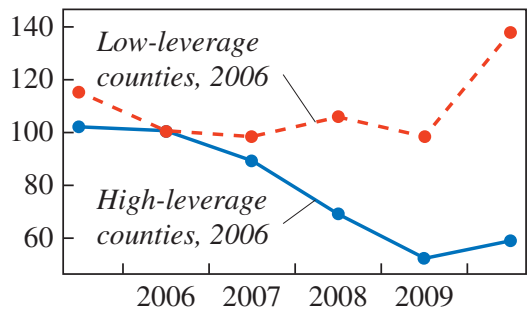

Nondurable, nongrocery

Index, $2006=100$

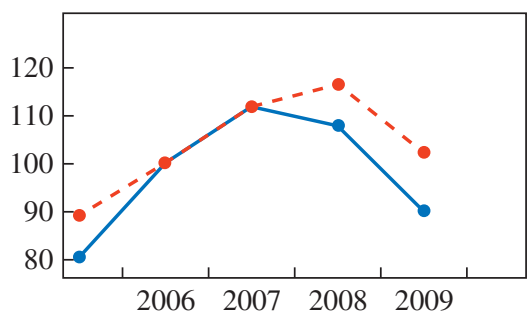

Durable goods

Index, $2006=100$

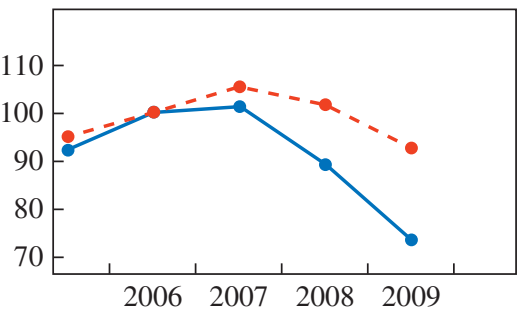

Groceries

Index, $2006=100$

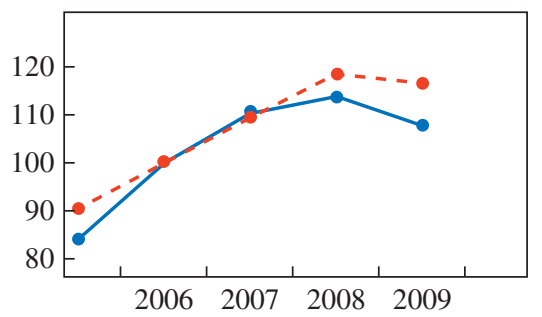

Source: Author's calculations using automobile data from R.L. Polk and other expenditure data from Mastercard Advisors; see Mian, Rao, and Sufi (2012) for details.

a. High-leverage and low-leverage counties are defined as in figure 1. Deciles are weighted by population.

coefficient. Mian and others (2012) estimate a variant of equation 1 using different consumption data from those used by Dynan. The first measure of consumption is based on purchases of new automobiles in a county, and the second on credit card spending patterns. The auto purchases data track changes in durables consumption, whereas the credit card transaction data cover a broader basket of consumption goods. Whichever measure of consumption is used, Mian and others (2012) find, as does Dynan, a strong effect of leverage on consumption.

My figure 2 illustrates the main result. Across a broad set of consumption measures, the drop in consumption is significantly stronger in counties with highly leveraged households. As already mentioned, these are also the counties that have seen the steepest drop in home prices. However, the magnitude of the effect is useful in understanding whether the result might be driven by a pure wealth effect. 
Mian and others (2012) estimate the elasticity of overall consumption with respect to a home price shock to be 0.44 . A pure wealth effect is unlikely to lead to such a high estimate, on both theoretical and empirical grounds. The argument from theory is as follows. Housing appears in the consumption basket as well as other goods and services. Thus, a reduction in home prices makes housing consumption cheaper for homeowners and their offspring. Similarly, in a simple life-cycle model, a $\$ 1$ reduction in permanent income reduces consumption today by $1 / N$, where $N$ is the remaining number of years in a lifetime. An elasticity of 0.44 is thus very high to be justified by a pure wealth effect. On the empirical side, historical estimates of the wealth effect that are not contaminated by the leverage effect are an order of magnitude smaller than the observed elasticity. For example, Raphael Bostic, Stuart Gabriel, and Gary Painter (2009) survey the literature and report estimates of between 0.05 and 0.17 .

Thus, the effect of leverage on the consumption decline is likely driven by other financial frictions. One possibility is lower access to credit due to the reduction in household net worth. Another is that reduced net worth and high indebtedness force households to pay down debt at the expense of consumption. ${ }^{1}$

Finally, the PSID data (both on consumption and on leverage and wealth) used in this paper are based on individual survey responses and thus are subject to measurement error and survey bias. Measurement error can lead to an attenuation bias. There is some evidence of weak statistical power when the data are cut along multiple dimensions. I suspect that data noise is the issue here. I bring up the issue of measurement error because, as I mentioned earlier, the magnitudes of the coefficients are quite important for interpreting the channels behind them.

GENERAL EQUILIBRIUM EFFECTS AND POLICY IMPLICATIONS The analysis in the paper is based on a cross-sectional comparison of households. It is possible that although there are strong cross-sectional effects of leverage on consumption, the aggregate effects are not as strong. For example, more-leveraged individuals might cut back sharply on consumption. But in general equilibrium such a cutback in consumption might put downward pressure on prices and interest rates. Individuals who are not constrained by leverage may respond positively to lower interest rates and boost their consumption. In fact, such a general equilibrium effect could further strengthen the cross-sectional results while mitigating the aggre-

1. See Mian and Sufi (2011b) on the impact of consumption cuts on employment. 
gate impact. A discussion of such general equilibrium effects would have been useful in the paper.

If household leverage or debt overhang has been important in pulling consumption back, what implications does that have for policy? As I mentioned at the beginning, the key factor on which to focus is the distributional shock. Aggregate consumption in such models is constrained by the net worth of the borrowing class. Thus, any policy that works to increase their net worth, such as principal reduction for underwater homeowners, is likely to be helpful. Similarly, practices that are part of traditional bankruptcy regimes, such as forcing foreclosures, may not be optimal because of their spillover effect of lowering home prices further and reducing the net worth of current homeowners. More broadly, macroeconomic policy in a world where consumption is driven by debt overhang needs to be seen through its implications for the net worth of the borrowing households.

\section{REFERENCES FOR THE MIAN COMMENT}

Bostic, Raphael, Stuart Gabriel, and Gary Painter. 2009. "Housing Wealth, Financial Wealth, and Consumption: New Evidence from Micro Data." Regional Science and Urban Economics 39, no. 1: 79-89.

Mian, Atif, and Amir Sufi. 2011a. "House Prices, Home Equity Based Borrowing, and the U.S. Household Leverage Crisis." American Economic Review 101: 2132-56.

. 2011b. "What Explains High Unemployment? The Aggregate Demand Channel." Working paper. University of California, Berkeley.

Mian, Atif, Kamalesh Rao, and Amir Sufi. 2012. "Household Balance Sheets, Consumption, and the Economic Slump." Working paper. University of California, Berkeley.

\section{COMMENT BY}

KAREN M. PENCE ${ }^{1}$ Home prices in the United States as a whole have fallen nearly 30 percent since early 2006 . Outstanding mortgage debt, however, continued to rise for 2 years after home prices began to fall and is now only about 7 percent below its peak. As a result, households are both poorer and more leveraged. Aggregate home equity has fallen around

1. I am grateful to Jesse Bricker, Brian Bucks, Jane Dokko, Charles Fleischman, Andrew Figura, Josh Gallin, Ben Keys, Michael Palumbo, and Claudia Sahm for helpful comments and conversations. The analysis and conclusions in this discussion are mine alone and do not indicate concurrence by other members of the research staff of the Board of Governors of the Federal Reserve System. 
50 percent, or by $\$ 7$ trillion, since early 2006 , and about a quarter of all mortgage borrowers are underwater. That households, on average, cut back on spending when their wealth falls is widely accepted, but whether household leverage affects consumption, holding wealth fixed, remains an open question. Put differently, it is unclear whether two households with the same amount of wealth, but different mixes of assets and debt, will differ in their consumption.

In this paper Karen Dynan explores this issue using household-level data from the Panel Survey of Income Dynamics (PSID). Like all of her work, the paper is beautifully written and reasoned, and the empirical work is cleverly and carefully done. In this discussion I will consider why high leverage might matter for consumption, explore why micro data are likely a better source than macro data for answering this question, and raise some issues about the interpretation of the results. Dynan's paper also includes some sobering statistics about the share of borrowers who are in distress on their mortgages.

High leverage is a problem for consumption primarily because it impedes the ability of homeowners to refinance their mortgages or sell their homes. Borrowers with little or no home equity face considerably more obstacles to refinancing their mortgages, and thereby boosting their consumption, than borrowers with identical declines in wealth but some remaining home equity. ${ }^{2}$ Similarly, low- or no-equity borrowers who face difficulties in selling their homes are less able to reduce their mortgage payments by moving to a smaller home, or to increase wage income by moving to a stronger labor market, and this has corresponding effects on their spending.

Households may also react to high leverage by developing a distaste for debt. For example, data from the Survey of Consumer Finances suggest that the share of households agreeing with the statement that "buying on credit is a good idea" fell from 31 percent in 2004 to 28 percent in 2007 and 22 percent in 2010 . Households might express this distaste by forgoing purchases of durable goods that typically require financing, such as automobiles or appliances, and by paying down existing debt more quickly than required by the contracts.

In practice, precautionary saving motives may be stronger for many households than "distaste for debt" motives, and households with such worries about the future might prefer to conserve their cash rather than pay

2. The revamped Home Affordable Refinance Program appears to have eased some of these constraints to refinancing for borrowers with mortgages guaranteed by Fannie Mae or Freddie Mac. 
down debt, especially mortgage debt. Under the tight mortgage lending standards that have prevailed since 2008 , borrowers will have difficulty accessing home equity in an emergency through a line of credit or a refinancing. In addition, borrowers who are concerned about possible home price declines might be reluctant to invest in their homes further.

In some cases, high leverage may lead to higher consumption, not less, because borrowers have the option to default on their mortgages. Imagine that one household purchases a $\$ 100,000$ home with cash, whereas an otherwise identical household purchases an identical home with a nomoney-down mortgage and puts $\$ 100,000$ in a savings account. If home prices then fall by half, the two households have the same net worth, but the first has no leverage and the second is deeply underwater. The second household can shed its mortgage through default, in which case its wealth - and presumably its consumption - will then be higher than that of the cash purchaser. Borrowers who still have equity in their homes, however, or who find the costs of default unacceptably high, will not find this option attractive.

Macroeconomic models of consumption typically do not include debt as an explanatory variable. Aggregate debt changes slowly over time, and has done so even in recent years, and data on aggregate debt have too little variation for its effect on consumption to be precisely estimated. In addition, households use debt both as a way to smooth consumption over time and as a payment method for purchasing goods and services. Thus, although debt can lead to an increase in consumption, consumption can also lead to an increase in debt, and this endogeneity further complicates estimation and interpretation.

Macro models of consumption that do not explicitly include household debt have performed fairly well in the last couple of years. My figure 1 shows a simulation of the saving rate that is based on a standard errorcorrection model of personal consumption expenditures. ${ }^{3}$ The explanatory variables in the model are net worth, disposable income, transfer payments, the federal funds rate, consumer sentiment, banks' willingness to lend, and changes in the unemployment rate; the coefficients on these variables are estimated on aggregate data from 1963 through 2007Q4. Although the simulation predicts a lower saving rate, and thus higher consumption, than occurred during the depths of the financial crisis, it matches the actual data fairly closely after mid-2009.

3. I am grateful to Claudia Sahm of the staff of the Board of Governors for providing this simulation. 
Figure 1. Personal Saving Rate, Actual and Simulated, 2007Q4-2011Q4

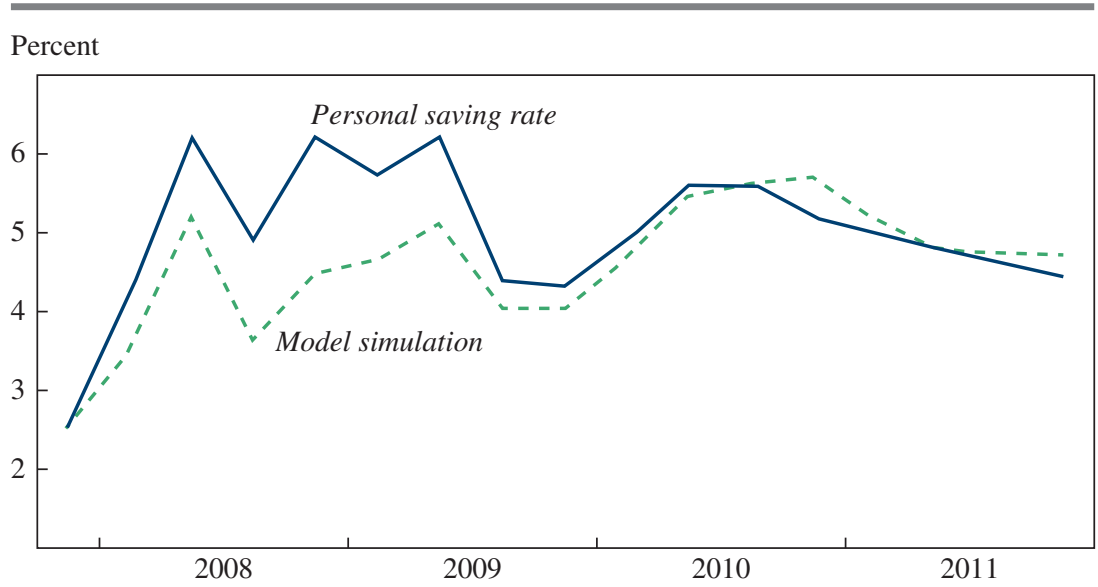

Sources: Bureau of Economic Analysis data and simulations by Claudia Sahm, Board of Governors of the Federal Reserve System.

a. Simulation is based on a standard error-correction model of aggregate personal consumption expenditures that includes net worth, disposable income, transfer payments, the federal funds rate, consumer sentiment, willingness to lend, and the change in the unemployment rate.

The strong performance of this model does not necessarily mean that leverage plays no role in consumption growth. In particular, the effect of debt may be captured by variables in the model that are correlated with leverage. For example, the "willingness to lend" variable, which comes from the Federal Reserve's Senior Loan Officer Opinion Survey, may be capturing the effect of tight credit standards on the consumption of borrowers with little or no equity in their homes.

Given the limitations of macro models, household-level analysis may be a more promising approach for exploring the effect of debt on consumption. In particular, the effects can be estimated more precisely because leverage varies more across households than aggregate leverage varies across time. Household-level data also allow for more precise estimation of the correlations among debt, wealth, and consumption.

In this paper Dynan regresses the 2007-09 change in household consumption on household leverage in 2007; the 2007-09 changes in wealth, income, and the state unemployment rate; and the age and education of the household head. By using the leverage data as of 2007, she avoids the endogeneity problem that debt, in its role as a payment mechanism, is a function of consumption. She finds that households with higher leverage in 2007 subsequently cut their consumption more than did their less 
Table 1. Household Characteristics by Mortgage Combined Loan-to-Value Ratio at Origination ${ }^{\mathrm{a}}$

\begin{tabular}{|c|c|c|c|c|}
\hline \multirow{2}{*}{$\begin{array}{l}\text { Combined loan-to- } \\
\text { value ratio }^{\mathrm{b}}\end{array}$} & \multirow{2}{*}{$\begin{array}{c}\text { Share of } \\
\text { households } \\
\text { (percent) }\end{array}$} & \multicolumn{2}{|c|}{$\begin{array}{l}\text { Net financial assets } \\
\text { (dollars) }\end{array}$} & \multirow{2}{*}{$\begin{array}{l}\text { Turned down for } \\
\text { credit }^{\mathrm{d}} \text { (percent of } \\
\text { households) }\end{array}$} \\
\hline & & Median & Mean & \\
\hline 100 percent or greater & 40 & $-4,835$ & 17,984 & 49 \\
\hline 90-100 percent & 23 & 11,860 & 48,561 & 46 \\
\hline 80-90 percent & 15 & 17,000 & 156,838 & 27 \\
\hline Less than 80 percent & 23 & 132,320 & 455,764 & 11 \\
\hline
\end{tabular}

Source: Author's calculations using data from the 2007 Survey of Consumer Finances (SCF).

a. The sample consists of homeowners who purchased their primary residence in 2006 or 2007 with a mortgage and had not refinanced that initial mortgage by the time of the survey. Farms, ranches, and mobile homes are excluded. Statistics are weighted with the SCF sampling weights.

b. Includes first, second, and third liens taken out at origination.

c. Savings, checking, and money market accounts; stocks, bonds, and mutual funds not held in taxfavored defined-contribution plans; Individual Retirement Accounts, 401(k)s, and other liquid definedcontribution plan balances; and the cash value of whole life insurance policies; minus credit card balances and other consumer loans.

d. Household was denied credit in the last 5 years or has not applied because of fear of being turned down.

leveraged counterparts, even with the controls for changes in wealth and other factors. This relationship is consistent across several specifications, although the coefficient on the leverage variable is often statistically insignificant because of the small sample size in the PSID and the noisiness of the wealth data.

However, this analysis does not escape the identification issues that plague macro models. In particular, households with high leverage are systematically different from other households. Some have high leverage because their initial down payments were small. These households tend to have fewer financial resources than households who made larger down payments, and so they may be forced to cut back their consumption more acutely in response to a job loss or other negative shock.

To illustrate this point, my table 1 displays selected characteristics of households in the 2007 Survey of Consumer Finances who purchased a primary residence with a mortgage in 2006 or 2007. Households are categorized by their combined loan-to-value (CLTV) ratio at the time of home purchase. In a reflection of the extraordinarily loose lending standards that prevailed at that time, 40 percent of these borrowers purchased their homes with no money down; an additional 23 percent made down payments of 10 percent or less. In 2007, borrowers with initial CLTV ratios of 100 percent or higher had median net financial assets of about $-\$ 5,000$, compared 
Table 2. Changes in Home Prices and Unemployment in California Metropolitan Statistical Areas, 2005-09

\begin{tabular}{|c|c|c|c|}
\hline \multirow[b]{2}{*}{ Metropolitan Statistical Area } & \multicolumn{2}{|c|}{$\begin{array}{l}\text { Change in home prices } \\
\text { (percent) }\end{array}$} & \multirow{2}{*}{$\begin{array}{c}\text { Change in } \\
\text { unemployment rate } \\
\text { 2007-09 } \\
\text { (percentage points }\end{array}$} \\
\hline & $2005-07$ & 2007-09 & \\
\hline Bakersfield-Delano & -21 & -36 & 6.2 \\
\hline Fresno & -19 & -32 & 6.4 \\
\hline Los Angeles-Long Beach-Santa Ana & -8 & -25 & 6.1 \\
\hline Modesto & -31 & -42 & 7.1 \\
\hline Riverside-San Bernardino-Ontario & -20 & -38 & 7.4 \\
\hline Sacramento-Arden-Arcade-Roseville & -24 & -28 & 5.8 \\
\hline San Diego-Carlsbad-San Marcos & -18 & -19 & 5.0 \\
\hline San Francisco-Oakland-Fremont & 1 & -18 & 5.2 \\
\hline San Jose-Sunnyvale-Santa Clara & -4 & -21 & 6.1 \\
\hline Santa Rosa-Petaluma & -19 & -25 & 5.3 \\
\hline Stockton & -33 & -40 & 7.1 \\
\hline Visalia-Porterville & -20 & -30 & 5.9 \\
\hline \multicolumn{3}{|l|}{ Correlation } & $\begin{array}{l}\text { Correlation } \\
\text { coefficient }\end{array}$ \\
\hline \multicolumn{3}{|c|}{$\begin{array}{l}\text { Between } 2005-07 \text { home price change and 2007-09 unemployment } \\
\text { rate change }\end{array}$} & -0.54 \\
\hline \multicolumn{3}{|c|}{$\begin{array}{l}\text { Between 2007-09 home price change and 2007-09 unemployment } \\
\text { rate change }\end{array}$} & -0.88 \\
\hline
\end{tabular}

Source: Author's calculations using data from CoreLogic and Bureau of Labor Statistics.

with $\$ 11,000$ for those with CLTVs of 90 to 100 percent, and $\$ 17,000$ for those with LTVs of 80 to 90 percent. The differences in mean net financial assets across these groups are even more dramatic. Further, borrowers with no or low down payments appeared to face restrictions on their access to credit even in 2007, and thus were less able to smooth consumption over time through borrowing: nearly half of these borrowers reported that they had been turned down for credit in the last 5 years or had not applied for credit because of fear of being turned down. ${ }^{4}$

Other households have high leverage because their homes have declined significantly in value. As areas with large home price declines also tended to see greater increases in unemployment, such households are more likely to lose jobs and thus decrease their consumption, or fear losing jobs and thus increase their precautionary saving, than homeowners in areas where home price declines were more modest. My table 2 shows the

4. I assume that a household's characteristics at the time of the 2007 interview are a reasonable proxy for their characteristics at the time of home purchase. 
changes in home prices and unemployment for 12 metropolitan statistical areas in California. For 2005-07 these changes ranged from essentially zero in San Francisco to a 33 percent drop in Stockton. The correlation between these changes and the 2007-09 change in unemployment is 54 percent; that between the 2007-09 changes in home prices and unemployment is nearly 90 percent. $^{5}$

Whether the coefficient on the leverage variable in Dynan's regressions captures the effect of leverage itself or of characteristics correlated with leverage depends on the other explanatory variables in the model. The age and education of the household head will proxy somewhat for the amount of household resources available to weather shocks, as will the change in household income. The change in state unemployment should control partly for the fact that high-leverage households are more likely to lose or fear losing jobs. That said, financial resources vary considerably within age and education groups, and labor market conditions may vary quite a bit within states. For example, the 2007-09 increases in unemployment within California ranged from 5 percentage points in San Diego to 7.4 percentage points in Riverside (table 2).

As in all such studies, the results also do not shed light on the mechanism by which debt affects consumption, which is a crucial consideration for policymakers. If debt weighs on consumption by impeding mortgage refinancing and home sales, policymakers may want to facilitate these transactions through streamlined refinancing programs such as the Home Affordable Refinance Program and improved short-sale programs. If instead households' discomfort with their level of debt is the main factor, programs that reduce mortgage principal might be an appealing option. And if debt weighs on consumption only through its effect on household wealth, policymakers may prefer more traditional methods of stimulating aggregate demand.

I conclude with some thoughts for future research. When home prices fall, homeowners become less willing to sell their homes, particularly if they are underwater on their mortgages or the sale would result in a nominal loss. Homeowners may be reluctant to sell because they are unable or unwilling to bring cash to the closing table, or because they are averse to taking nominal losses. As a result, both repeat-sales home price indexes and homeowner reports of their home values may suffer from opposing biases during home price downturns. In the case of repeat-sales indexes, if homeowners hold their homes off the market, the transactions reflected

5. Williams (2012) shows a similar relationship with state-level data. 
in the index will be dominated by foreclosures and short sales, which tend to garner lower prices. In contrast, if homeowners are in denial about the extent of home price declines, their reports of their home values may exceed the true market values. More research is needed on the extent and severity of these biases, on whether perceived or market home prices matter more for consumption, and on how a correlation between the home price cycle and the accuracy of home price data might affect the estimation of macroeconomic models.

\section{REFERENCE FOR THE PENCE COMMENT}

Williams, John C. 2012. "Discussion of 'Housing, Monetary Policy, and the Economy' " at the Monetary Policy Forum, New York, February 24. www.frbsf.org/ news/speeches/2012/john-williams-0224.html.

GENERAL DISCUSSION The paper demonstrated for Christopher Carroll that the Panel Study on Income Dynamics could provide valuable insights into household consumption patterns. In his view a key question the paper addressed is whether a household's consumption is purely a function of its net worth, or whether the breakdown of net worth into assets and debt affects consumption, too. For that question he thought the debtto-income ratio and the assets-to-income ratio might be better variables to include in the right-hand side of the regression than the debt-to-assets ratio and the debt-service ratio, as Dynan had specified it. The debt-to-income ratio also seemed to Carroll preferable to the debt-to-assets ratio because a large fraction of households have few assets aside from their home.

Carroll also described related research in which he and coauthors regressed the aggregate household saving rate on three variables: the aggregate wealth-to-income ratio, a measure of aggregate credit supply, and unemployment expectations. Their measure of credit supply was derived from data from the Federal Reserve's Senior Loan Officer Opinion Survey. Together, the three variables explained the path of the aggregate saving rate very well, including during the recent recession. An increase in unemployment expectations explained a large part of the run-up in saving in the recession, which Carroll took as evidence that this saving was motivated by rising fears of job loss. Increasing credit supply, meanwhile, explained a long-term decline in the saving rate over the past few decades, but the reduction in that supply at the onset of the recession was estimated to be a fairly unimportant factor in the run-up in saving. Jan Hatzius warned, however, that the loan officer survey probably underestimates the loosening of credit availability over the past 10 years because it virtually ignores shadow banks. 
Robert Hall thought Dynan had chosen the right regression specificationwith the change in consumption on the left-hand side and the level of precrisis debt on the right-hand side- to examine how highly indebted households reacted to credit tightening during the recession. He thought some of the criticism of Dynan's analysis misinterpreted her baseline regression as an estimate of a household consumption function, which would appropriately have the level of consumption as its left-hand-side variable.

Hall noted that although the paper lacked a discussion of theory, its results were consistent with the theoretical predictions of a recent paper by Veronica Guerrieri and Guido Lorenzoni at the University of Chicago. Using a model formulated by Truman Bewley in the 1970s, they found that following a credit crunch, households will first reduce their spending so as to deleverage, assuming they avoid default, and then continue to consume less to build up precautionary savings before restoring consumption to its original level.

Karl Case mentioned work he had done recently with John Quigley and Robert Shiller, which found that the wealth effect is an important determinant of consumption when asset values are rising but less important when they are falling. He took this result as evidence that households' perceptions of their wealth are downwardly sticky. Case had also been eagerly investigating new survey data on household consumption patterns. In preliminary work with these data, he had found that computing changes in household savings as changes in net worth, as opposed to income-minus-consumption, could help explain household behavior. He also observed that, in this data set, housing prices seemed resistant to forces that would push them down, which made it difficult to evaluate the relationship between housing wealth and household spending.

Jan Hatzius highlighted two potential explanations of the paper's result that a rise in a household's debt predicts a decline in that household's consumption. The result could mean that high indebtedness itself induces a household to reduce its consumption, or it could mean that changes in housing wealth have a larger marginal impact on consumption than the typical wealth effect of 3 to 5 cents per dollar. Such would be the case if, in addition to the usual wealth effect, housing wealth affects consumption through its shaping of a household's credit constraints, by serving as collateral for loans. The first explanation implies bleak prospects for household consumption growth over the next few years, because debt levels among households that were highly leveraged at the onset of the recession are still quite high. The second explanation, however, suggests a brighter outlook, 
because it implies that the impact of a change in housing wealth on consumption is felt as housing prices fall and credit tightens. In this scenario, the major adjustment process for consumption would already be past.

Donald Kohn, like Hatzius, wondered whether changes in consumption are driven more by changes in credit availability or by debt. He thought one way to help distinguish between these channels might be to compare households that default with those that refinance or short-sell their homes, since both groups deleverage, but only households that go through foreclosure experience sharp reductions in their credit availability.

Martin Feldstein found the current high number of defaults unsurprising, given that a quarter of all homes with mortgages are underwater today and that the median loan-to-value ratio of underwater homes is 130 percent. Defaulting both wipes out debt and changes the defaulter's credit conditions, which led Feldstein to wonder how individuals behave leading up to and following a default. When people are still living in their homes but have stopped making loan payments, do they save more in anticipation of foreclosure?

Michael Woodford thought it quite plausible that the negative coefficients on the debt-to-asset ratio and the debt-service ratio in Dynan's regressions were driven by a debt-service effect, but he suggested another possible interpretation: Surely consumption spending should depend not only on current assets and current income but also on expectations of future income. So, perhaps, people with higher debt ratios were also people whose expectations of future income fell more than others', which, in turn, drove them to reduce their consumption more. Such a correlation might exist if, before the crisis, people who were unusually optimistic about their prospects for income growth were willing to borrow more, and then, when the crisis hit, their expectations of future income fell more than others' because of regression to the mean. This story would have very different policy implications than a story about debt service forcing consumption reductions, since it would imply less of an opportunity for mortgage principal reductions to boost aggregate demand. He wondered, then, if there was a way to determine which story is correct.

Ricardo Reis thought it would be interesting to investigate the effect of debt on labor supply and human capital investment as well as on consumption. He reported an observation that had come out of the international trade and finance literature: firms and countries that take on large debts may reduce their future investment in high-net-present-value projects, because they realize they will owe a significant fraction of their returns to their previous creditors. Household behavior might prove similar. 
Gerald Cohen noted that most of the decline in consumption during the recent recession had come from the durable goods category, which he thought lent support to Reis's theory, since it was consistent with the possibility that individuals were worried about losing their durable goods purchases to creditors.

Reis proposed two potential answers to Pence's question about why so many people appear to be overvaluing their homes since the collapse of the housing bubble. First, he noted that any time prices change suddenly, some individuals update their beliefs about prices more quickly than others. Research he had done with Justin Wolfers and Gregory Mankiw, for example, had found that many people started making large errors in forecasting inflation after inflation began falling rapidly in the early 1980s. Second, he noted that before the collapse of the housing bubble, more people were prospective buyers of homes, whereas during and following the collapse, more people became prospective sellers. In surveys, prospective buyers may be more likely to value homes for their true worth or less, whereas prospective sellers may be more likely to overstate their home's value. This could be true either for reasons of bargaining strategy or for reasons deriving from behavorial economics, which finds that people tend to value items they own more highly than objects they are considering purchasing.

Carroll questioned Reis's first theory, noting that Pence had found that beliefs about prices were sticky only on the way down, not on the way up. Reis, however, thought it was inappropriate to compare the stickiness of beliefs about housing prices before the crash and during it, since those prices rose at a very steady rate over the years leading up to the crash, making it easier for individuals to update their beliefs about prices correctly, whereas prices fell very rapidly and thus surprisingly on their way down.

Justin Wolfers suggested a third theory for the prevalence of incorrect beliefs about housing prices following the crash, which is that people are loss averse and thus psychologically unwilling to realize losses.

Janice Eberly thought it was helpful that Dynan's data included both first and second liens in the calculation of individual households' debts, because second liens represent a significant fraction of debt among the most indebted households. In other data sources, such as data from lenders, it was either difficult or impossible to match first and second liens to individual households.

Eberly also thought that Dynan's data could help shed light on an important policy debate: Are defaults driven by high debt, payment distress associated with a high debt-service ratio, or some combination of the two? If default is driven mostly by the level of debt, principal reductions may be a 
helpful intervention to reduce rates of default, whereas if payment distress is the bigger issue, payment modifications may be most effective. The more willing households are to reduce their consumption to service debt, the less likely mortgage modifications of any kind are to reduce rates of default, although they may still have the desirable effect of increasing aggregate consumption.

Alan Blinder asked whether the data shed light on the debate about whether housing wealth constituted net worth for the majority group of borrowers who are not looking to buy or sell.

Responding to the discussion, Dynan thought it impressive that the model of Carroll and his coauthors could fit aggregate consumption very well using only three variables - unemployment expectations, credit conditions, and wealth-but that it was still important to explain consumption patterns at a household level because the aggregate data do not allow researchers to distinguish among the causes of reduced consumption. Unemployment expectations data might reflect changes in sentiment that are influenced by changes in credit constraints, which would bias the measured impact of the credit conditions index, for example.

Like Atif Mian in his formal comment, Dynan had worried that the coefficients on her debt regressors could be biased downward if lowwealth households have higher marginal propensities to consume, since these households are more likely to be highly leveraged. One way she investigated these concerns in the paper was by running the same regression for the 2005-07 period, when home prices were rising. If differences in marginal propensities to consume were driving the results, one would expect to observe positive coefficients on the debt regressors in this period, since housing wealth was growing, but in fact the coefficients on the debt regressors were still negative, suggesting that high debt itself was putting a damper on households' consumption. Nevertheless, she thought that more work needed to be done to determine the root causes of changes in consumption. She also agreed with Hatzius and Kohn that it was important to distinguish the negative wealth effect of high debt on consumption from the effect that high debt has on consumption through tightening credit constraints. Finally, she agreed with Eberly and Feldstein that it would be interesting to examine the behavior of defaulting households in more detail but thought that the small sample size of the PSID limited one's ability to do so. 